April 2008

\title{
Kurds in Turkey and in (Iraqi) Kurdistan: A Comparison of Kurdish Educational Language Policy in Two Situations of Occupation
}

Tove Skutnabb-Kangas

Follow this and additional works at: https://digitalcommons.usf.edu/gsp

\section{Recommended Citation}

Skutnabb-Kangas, Tove (2008) "Kurds in Turkey and in (Iraqi) Kurdistan: A Comparison of Kurdish Educational Language Policy in Two Situations of Occupation," Genocide Studies and Prevention: An International Journal: Vol. 3: Iss. 1: Article 5.

Available at: https://digitalcommons.usf.edu/gsp/vol3/iss1/5

This Articles is brought to you for free and open access by the Open Access Journals at Digital Commons @ University of South Florida. It has been accepted for inclusion in Genocide Studies and Prevention: An International Journal by an authorized editor of Digital Commons @ University of South Florida. For more information, please contact digitalcommons@usf.edu. 


\title{
Kurds in Turkey and in (Iraqi) Kurdistan: A Comparison of Kurdish Educational Language Policy in Two Situations of Occupation
}

\author{
Tove Skutnabb-Kangas ${ }^{1}$ and Desmond Fernandes ${ }^{2}$ \\ ${ }^{1}$ Professor Emerita, Universite of Roskilde, Denmark, and Abo \\ Akademi University, Finland \\ ${ }^{2}$ The Campaign Against Criminalising Communities (CAMPACC)
}

\begin{abstract}
This article describes, compares, and analyzes two educational situations for Kurds from the point of view of linguistic human rights, using prodigious exemplification. In Turkey, Kurdish-medium schools are not allowed, and Kurdish children do not even have the right to study their mother tongue as a subject in school. In addition to physical genocide through low-intensity warfare, including unacceptable living conditions, Turkey continues to commit linguistic and cultural genocide (according to definitions of genocide in articles 2(b) and 2(e) in the UN Convention on the Prevention and Punishment of the Crime of Genocide) in relation to the Kurdish nation/minority. Under the US-led occupation in Iraq, Kurdish children in (northern Iraqi) South Kurdistan are educated mainly through the medium of Kurdish and learn several foreign or second languages at school; minorities have their own schools in their own languages. We are especially interested in understanding how similar background motives on the part of Turkey's and Iraq's "partners" (mainly the United States) can result in such different educational outcomes. Thus we discuss some of the possible ethno-sociological, historical, economic, military, and political reasons for the differences and similarities, especially analyzing the seemingly contradictory US policy vis-à-vis the Kurds (including Kurdish language rights in education) in terms of three main causal factors: the US wish to secure oil, energy, and water deliveries in a new situation of uncertainties, through Turkey and from Iraqi Kurdistan; to secure support from Turkey in restructuring the Middle East; and to secure new arms deals.
\end{abstract}

Keywords: genocide, Kurd, Turkey, Iraq, educational language rights

\section{Introduction}

Kurds, some 25 to 35 million people, have been said to be the world's largest people without a state. In Turkey, even speaking Kurdish in public places has been forbidden until recently. Kurdish-medium schools are not allowed; Kurdish children do not even have the right to study their mother tongue as a subject in Turkish schools. In theory, courses in the Kurdish language can be taught to teenagers and adults, but in practice the obstacles and conditions have been so many, and so bureaucratically and legally demanding, that almost no such courses are offered. Kurds are under Turkish occupation. In addition to physical genocide through a low-intensity warfare

Tove Skutnabb-Kangas and Desmond Fernandes, "Kurds in Turkey and in (Iraqi) Kurdistan: A Comparison of Kurdish Educational Language Policy in Two Situations of Occupation." Genocide Studies and Prevention 3, 1 (April 2008): 43-73. (C) 2008 Genocide Studies and Prevention. doi: $10.3138 /$ gsp.3.1.43 
that includes unacceptable living conditions, ${ }^{1}$ Turkey continues to commit linguistic and cultural genocide (according to definitions of genocide in articles $2(\mathrm{~b})$ and $2(\mathrm{e})$ of the UN Convention on the Prevention and Punishment of the Crime of Genocide) in relation to the Kurdish nation/minority. ${ }^{2}$

Under the US-led occupation in Iraq, Kurdish children in (northern Iraqi) South Kurdistan, which has its own regional government, ${ }^{3}$ are educated mainly through the medium of Kurdish and learn several foreign or second languages at school. Minorities (Turkmens, Assyrians, etc.) have their own schools in their own languages. In 2006, Abdul-Aziz Taib, then minister of education in the Kurdistan Regional Government (KRG), said that every child in the world has the right to be educated through the medium of his or her mother tongue(s). ${ }^{4}$

This article describes, compares, and analyzes these two educational situations, including some of the possible ethno-sociological, historical, economic, military, and political causes for their differences and similarities, from the point of view of linguistic human rights. The approach needs to be multidisciplinary in order to do justice to the enormous complexity of the issues. This is challenging in a short article; interested readers should refer to our other writings on the topic. ${ }^{5}$ We are especially interested in understanding how similar background motives in Turkey's and Iraq's "partners" (e.g., the United States) can result in such different educational outcomes. It is also interesting, at least in terms of educational policy, to see a rare positive example in which the earlier oppressed (Kurds in Iraqi Kurdistan) do not

Table 1. Estimates of numbers of Kurds

\begin{tabular}{lll} 
State & Source: Kemal Burkay & Source: Wikipedia \\
\hline Turkey & $18-20$ million & $14-21$ million $^{\mathrm{a}}$ \\
Iraq & 5 million & $4-6$ million $^{\mathrm{b}}$ \\
Iran & $8-10$ million & $4.8-6.6$ million $^{\mathrm{c}}$ \\
Syria & 1.5 million & $0.9-2.6$ million $^{\mathrm{d}}$ \\
Total & $32.5-36.5$ million & $23.7-36.2$ million \\
\hline
\end{tabular}

Sources: Kemal Burkay, "The Kurdish Question-Its History and Present Situation," http://members.aol.com/KHilfsvere/Kurds.html (accessed 9 January 2008); Kemal Burkay is the general secretary of the Kurdistan Socialist Party. "Kurdish People," Wikipedia, http://en.wikipedia.org/wiki/Kurdish_people (accessed 9 January 2008).

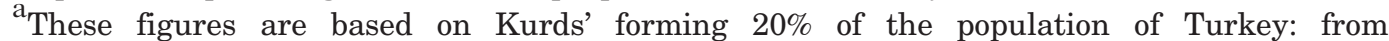
$70,400,000 \times 20 \%$ to $74,709,000 \times 20 \%$. The World Factbook, s.v. "Turkey" (Langley, VA: Central Intelligence Agency, 2006), https://www.cia.gov/cia/publications/factbook/geos/tu.html (accessed 22 January 2007); World Gazetter, ed. Stefan Helders, s.v. "World" (Leverkusen, Germany: Stefan Helders, 2006), www.world-gazetteer.com/wg.php (accessed 22 January 2007). We use Wikipedia as a source here because it gives a good summary and its references can be checked.

${ }^{b}$ Estimate based on $26,783,383 \times 15 \%(=4,017,450)$ to $26,783,383 \times 20 \%(=5,357,000)$. World Factbook, s.v. "Iraq"; Encyclopedia of the Orient, ed. Tore Kjeilen, s.v., "Iraq: Religions and Peoples" (N.p.: Lexorient, 2006), http://lexicorient.com/e.o/iraq_4.htm (accessed 9 January 2008). "Estimate based on 68,688,433 × 7\%. World Factbook, s.v. "Iran"; Encyclopedia of the Orient, s.v. "Iran: Religions and Peoples," http://lexicorient.com/e.o/iran_4.htm (accessed 9 January 2008).

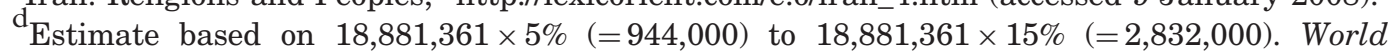
Factbook, s.v. "Syria"; Encyclopedia of the Orient, s.v. "Syria: Peoples. Languages. Religions." 
turn into (linguistic) oppressors of others when they gain some power to control their own destiny.

Exact figures for the number of Kurds in the world are not available, because most states where they live have not wanted and still do not want to know. Kurds have not been included in any census as Kurds, and questions about ethnicity and mother tongue have not been asked. In addition, respondents fear reprisals for self-identifying as Kurds, and Middle Eastern authorities prefer to minimize numbers of Kurds. ${ }^{6}$ However, many Kurdologists concur with David McDowall's estimate that there were at least 22.6 million Kurds worldwide around 1990, and with the estimate that $20 \%$ to $25 \%$ of the population of Turkey is Kurdish. ${ }^{7}$ Various sources estimate the number of Kurds in Turkey at a minimum of 15 million, ${ }^{8}$ and some posit $20 \%$ of the population of Turkey, but figures up to 30 million have been used.

Millions of Kurds have been killed since Mustafa Kemal Atatürk came to power in 1923, and at least 3 million Kurds are internally displaced in Turkey today.

The number of Kurds in diaspora has been estimated as follows: ${ }^{9}$ Germany, 500,000-600,000; Afghanistan, 200,000; Azerbaijan, 150,000; Lebanon, 80,000; Armenia, 42,139; Turkmenistan, 40,000; United Kingdom, 25,000; ${ }^{10}$ Israel, 100,000; ${ }^{11}$ Sweden, 30,000; ${ }^{12}$ Georgia, 34,000-60,000. ${ }^{13}$ This list, which excludes several countries with sizable numbers of Kurds (e.g., Australia, Canada, Denmark, the United States), adds up to a total of some 1.231 to 1.357 million. Thus, the total number of Kurds in diaspora might be around 1.5 million.

Educational linguistic human rights, especially the right to first-language-medium education, are among the most important rights for all indigenous peoples and minorities. Without them, a minority/people whose children attend school usually cannot reproduce itself as a minority/people. It cannot integrate but is forced to assimilate. Next we describe the educational situation in two parts of Kurdistan in relation to these rights.

\section{The Kurdish Language-in-Education Situation in (Turkish) Northwest Kurdistan and (Iraqi) South Kurdistan}

\section{Kurdish Educational Language Policy in Turkey}

The situation in Northwest Kurdistan (Turkey) is easily described: Kurdish-medium schools are not allowed in Turkey, nor do Kurdish children have the right to study their mother tongue as a subject in school. Courses in the Kurdish language can in theory be offered for teenagers and adults, but the obstacles and conditions imposed have been such that, at the time of writing, virtually no such courses existed. The conditions imposed on private schools manifestly discourage Kurdish-language education or courses: "Sixteen conditions were outlined in the memo on the authorization of Kurdish tuition on a private basis... For the head of the teachers' union in Diyarbakir,... Kurdish courses had been permitted" de jure, "but... under these conditions they were, in fact, "simply impossible" "for appropriate teaching. ${ }^{14}$ According to Mariam Benitez and David Lawson, "the Turkish Government has repeatedly linked Kurdish language and culture to separatism and terrorism."15

The following examples from 2002 through 2007 are drawn mostly from court cases in which the Kurdish language and expressions in support of Kurdish culture/ language were either overtly prohibited or prohibited on the basis of being labeled "terrorist activities" under the vague definition of terrorism in various articles of the Turkish Penal Code. 
The first two instances took place during the summer of 2002 :

On 14th August 2002, a hearing took place in Number Four court of the state security courts in Istanbul against twelve teachers and functionaries from the trade union Egitim-Sen. They were accused of giving talks at various trade union congresses between $2-13$ th February on the right to native [i.e., Kurdish] language tuition and had, therefore, given support to the ['terrorist'] PKK... The defendants deny the charges. ${ }^{16}$

A case has begun before the state security court in Diyarbakir against 27 children aged between 11-18, because they had demanded the right to native [Kurdish] language tuition... The state prosecutor... accuse[d] the children and adolescents of "aiding a terrorist organization" through their demands, and has called for prison terms of 3 years and 9 months. ${ }^{17}$

Also in 2002, students' petitions calling for the right to merely receive optional instruction in the Kurdish language were incriminated

on grounds of being instrumental to the [“terrorist"] PKK's efforts to establish itself as a political organisation. State Prosecutors were briefed by the Ministry of the Interior in January, 2002, to bring charges of "membership in a terrorist organisation" punishable with 12 years imprisonment against any students or parents who lodge[d] petitions demanding optional Kurdish lessons. By 23 January 2002, a total of 85 students and more than 30 parents ha[d] been imprisoned and over 1,000 people (among them some juveniles) detained for [merely] having demanded optional first language education in Kurdish. $^{18}$

Even today, as Turkey is engaged in the EU accession process, "programs in Kurdish for children on radio or TV" remain "prohibited," according to Jon Rud. ${ }^{19}$ "Local media groups who seek [to] broadcast programs in languages and dialects other than Turkish [i.e., Kurdish] ... will [need to] present... an affidavit" clarifying their intentions and behavior, "stating that they will not broadcast... programs with the aim of teaching that language."

Teachers who have sought simply to learn the Kurdish language, in preparation for a time when they might be allowed to teach it in schools, have also been targeted: "12 people of whom 11 were teachers," we are told,

were allegedly tortured while being detained by police after having been arrested in Kiziltepe for learning Kurdish together. The 12 people, 11 of whom were members of the teachers['] trade union Egitim-Sen, were arrested in an apartment... in Mardin on May 7th. A magistrate had issued warrants for their arrest. The Mardin branch of Egitim-Sen said in a written statement that... "Our colleagues were subjected to various methods of torture; they were sprayed with high-pressure water, they had plastic bags pulled over their heads, they were forced to sing marching songs and to do the goose-step, they were brutally beaten, left for 3 days without food or water, they were stripped naked, had their testicles crushed and were verbally abused." One of the teachers... was not spared the torture despite being pregnant. Because of her poor condition she was taken to Diyarbakir's Medical Faculty on the evening of her detention. According to the statement, her condition remains serious. EgitimSen ... pointed out that there was a complete disregard for legal procedures following the arrests. Despite complaints from their lawyers, between 25-30 police were involved in the questioning. ${ }^{21}$

In April 2004 it was reported that a "case against the members of KESK Music Group...who were charged with having sung in Kurdish during a festival organized by teachers' union Egitim-Sen in Diyarbakir in 2002, was restarted on 2nd April [2004]."22 


\section{A 2004 European Commission report confirms that}

in March $2004 \ldots$. RTUK ordered the closure for 30 days of ART TV, a local television channel broadcasting from Diyarbakir, on the grounds that it had violated "the principle of the indivisibility of the state" when, in August 2003, it broadcast two Kurdish love songs. ${ }^{23}$

Similarly,

RTUK issued a warning to one TV channel which had shown a music program with songs in Kurdish. This was based on a provision which prohibits programs that are "in breach of the general principles of the Constitution ... national security ..."

In 2006 the Swedish news agency TT reported that

on the 25th of August, 2006 the Turkish authorities in Istanbul have seized 1,208 Kurdish versions of the books about Pippi Långstrump (Pippi Longstocking), the worldfamous fictional children's character. They were sent on the 7th of August from Sweden by an organization that runs an education project for Kurds. The books had been sent for delivery to libraries in five Kurdish villages. As it is well known, Astrid Lindgren's books about Pippi Longstocking have been translated into 85 languages and published in more than 100 countries. $^{25}$

As Richard Boudreaux writes,

Kurds who dominate the [southeastern] region in numbers insist on the right to hear broadcasts and study in their own language and to give their children [Kurdish]...names...Turkey's rulers resist these demands as subversive.... Military police have swept through Kurdish towns and villages, checking birth certificates of infants and toddlers. Citing a constitutional clause that children must be named "in a manner appropriate to our national culture, moral principles and customs," the Interior Ministry has quietly instructed prosecutors to annul hundreds of children's Kurdish names and replace them with Turkish equivalents. At least 39 families resisting the orders have been taken to court, according to the bar association in Diyarbakir... Some of them have been threatened with prosecution for "separatist propaganda," which carries a three-year prison term. ${ }^{26}$

In June 2007, “Turkey's highest administrative court, the Council of State ruled ... to dismiss Abdullah Demirbas, Mayor of the Sur district of Diyarbakır because the municipality voted for the provision of services in languages other than Turkish." ${ }^{27}$ For the Kurdish Human Rights Project (KHRP), this action "represents the latest example of the central government's inflexible and intolerant stance on linguistic rights":

The recent court ruling against the mayor and council stemmed from a complaint lodged by the Interior Ministry. The board of judges voted unanimously in favor of dismissing Demirbas and the local council... The Diyarbakır chief prosecutor further demanded that Demirbas and Diyarbakır metropolitan mayor Osman Baydemir both be sentenced to a prison term of three and a half years. Twenty-one other defendants in the court case are also facing jail terms of three and a half years each. These prosecutions are currently pending. ${ }^{28}$

The Turkish Daily News confirms that

the country's top administrative court...dismissed the mayor.... and disbanded the municipal assembly over deciding to provide their services in Kurdish, Assyrian and English languages in addition to Turkish... It argued that the municipality's decision violated the constitution and Turkish law... The constitution states that no language apart from Turkish can be used in public services. ${ }^{29}$ 
A 2006 report by the "pro-Kurdish" Democratic Society Party (DTP), published with the DTP's permission in a blog run by an investigative journalist, also confirms the following legal actions targeted at Kurdish interests:

- On March 20, 2006, a case was filed against Mayor Demirbas on the grounds of "making propaganda to promote the aims of the terrorist organization PKK" due to his speech titled, "Municipal Services and Local Governments in the Light of Multilingualism," which was delivered at the European Social Forum in January 2006. Although the content of the speech, very well summarized by its title, did not include any single direct or indirect reference to the PKK, as was also later affirmed by the court, the very fact that the speech aimed to explore the relations between multilingualism and local democracy and that it was delivered by a DTP Mayor was enough to render it as a form of "PKK propaganda" in the eyes of central government authorities. Mayor Demirbas was acquitted from all charges on September 19, 2006. [The] public prosecutor's consequent appeal to the Supreme Court is still in process.

- On February 7, 2007, following the release of the Kurdish translation of Ubuntu, a free software program available in 167 languages, with the support of Sur Municipality, an investigation was launched against Mayor Demirbas and three municipal administrators on charges of "misuse of municipal resources."

- On October 10, 2006, [the] Ministry of [the] Interior launched an investigation against Mayor Demirbas due to the children's games and handicrafts book published by the Sur Municipality. The children's book, which was written in both Turkish and Kurdish, was published on the occasion of Teacher's Day.

- In March 2006 an investigation was launched against Mayor Demirbas due to his use [of] Kurdish in his speeches during a wedding ceremony in Diyarbakir.

- On April 19, 2007, Osman Baydemir, Mayor of Diyarbakir Metropolitan Municipality, will appear before the court on charges of violating the law that obliges state agencies, civic groups and private institutions to use Turkish letters. Mayor Baydemir risks 6 to 12 months of imprisonment for using the Kurdish letter "w" in his greetings cards of New Year's Day....

- On March 5, 2007, [the] Ministry of [the] Interior sent inspectors to Diyarbakir for a preliminary investigation against Democratic Society Party mayors due to the Newroz invitation cards published in Kurdish and sent to the officials in Turkey.

- In March 2007, a preliminary investigation was launched against Mayor Baydemir due to the publication of public brochures on health and cleanliness in Kurdish and Turkish for local people.

- In March 2007, a preliminary investigation was launched against Mayor Baydemir due to the baby names' book published in Kurdish.

- On January 17, 2007, an investigation was launched against Mayor Osman Baydemir due to the invitation cards sent to the officials in Turkey. The invitation cards, which were written in both Turkish and Kurdish, were sent on the occasion of the 6th Culture and Arts Festival in Diyarbakir.

- On January 12, 2007, a preliminary investigation was launched against Mayor Osman Baydemir due to the website of Diyarbakir Metropolitan Municipality, which is in Turkish, Kurdish and English.

- With an investigation filed on July 8, 2006, [the] Viransehir Mayor ... was indicted on charges of "misuse of municipal resources" due to publication of bulletins about municipal services both in Turkish and Kurdish. Mayor Cin stated that Kurdish was the mother tongue of the majority of...Viransehir's population (app. 120[,]000), thus, in publishing bulletins also in Kurdish, the municipality aimed to better communicate municipal services to the public....

- On October 20, 2006, a preliminary investigation was launched against [the] Kayapinar Mayor...due to the provision "Municipalities take the necessary 
precautions to teach their personnel Kurdish in order for them to better communicate with the public" [that was] stated in the collective agreement between the municipalities and the Union of Municipal and Local Governments Services Workers.

- Kayapinar Municipal Council's efforts to give culturally significant Kurdish names to the parks and streets of Diyarbakir were obstructed by the Diyarbakir Governorship because these names were said to either include letters that did not exist in the Turkish alphabet (e.g. "w") or showed parallelism with socially discriminating, separatist discourses. The court case filed by the Kayapinar City Council against the Diyarbakir Governorship is still in process.

- There are investigations against Diyarbakir Metropolitan, Kiziltepe, Sur and Silvan Municipalities opened solely for the use of Kurdish language in public speeches. ${ }^{30}$

Clearly, the linguistic human rights situation remains precarious. The chair of Turkey's Human Rights Foundation (TIHV) has said that

other than 14 articles that needed to be changed in the current Turkish Penal Code, various laws such as the Anti-Terror Law, the Law to Protect Atatürk, the Press Law and the RTUK [Radio and Television Higher Board] Code restricted freedom of expression. $[\mathrm{He}]$ said that in order for freedom of expression to settle in Turkey, the soul and essence of all of these laws needed to be changed... "Unless this happens," he said, "there will be no meaning in the amendments. And whether or not the cases opened and heard under these articles lead to an acquittal, they still mean intimidation through justice."31

Martin Scheinin, UN Special Rapporteur on the Promotion and Protection of Human Rights and Fundamental Freedoms while Countering Terrorism, has also concluded that Turkey's anti-terrorism bill (now passed into law) "introduces 'improper restrictions on freedom of expression... This danger is exacerbated by the very broad definition of terrorism' that is being used 'and the very long and wide list of terrorist offences." 32 The article that has been criticized most intensely in negotiations over Turkey's EU membership is art. 301, which criminalizes the act of "public denigration" of "Turkishness," the Republic of Turkey, the Grand National Assembly, the judicial institutions of the state, the military, or security.

It is clear that many of these laws constrain educational and linguistic human rights, and, in the US-backed war against "PKK terrorists," 33 it is already apparent that one line of reasoning being used "in Turkish legal practice is," indeed, "guilt by association." "34 An example of this reasoning in relation to education:

1. The terrorist organisation the PKK is making propaganda for the right to use the Kurdish language, including in education.

2. Consequently, anyone who advocates the right to use the Kurdish language is guilty of supporting ("aiding and abetting," Article 169 of the Turkish Penal Code) a terrorist organisation. $^{35}$

Even if many legal changes have been accepted (at least on paper), it is valid to conclude that Turkey is not yet even approaching international standards of human rights, either in education or in other aspects of linguistic rights. The situation has deteriorated since 2004. Although many other countries participate in linguistic and cultural genocide in relation to minorities, Turkey is unfortunately one of the worst offenders in the world, in several ways the worst.

\section{Kurdish Educational Language Policy in South Kurdistan (Northern Iraq)}

In South Kurdistan (northern Iraq), where Kurds form a large majority of the population of 5.5 million, they are in a completely different situation. The area of South Kurdistan (approximately $80,000 \mathrm{~km}^{2}$, about $18 \%$ of the total area of Iraq), comprises 
the governorates of Arbil, Sulaimania, Dohuk, Kirkuk, and parts of Dyala and Nineva. Two-thirds of the 5 million Kurds in Iraq live in the first three. ${ }^{36}$ These governorates are under the administration of the KRG; ${ }^{37}$ the others are still administered by Iraq.

During Saddam Hussein's regime, all education in South Kurdistan-where it existed at all-was delivered in Arabic. Kurds have themselves had administrative control over education since 1991, when the "safe haven" (no-fly zone) was created. The new constitution of Iraq (dating from 15 October 2005) states, in article 4,

First: The Arabic language and the Kurdish language are the two official languages of Iraq. The right of Iraqis to educate their children in their mother tongue, such as Turkmen, Syriac, and Armenian, in government educational institutions in accordance with educational guidelines, or in any other language in private educational institutions, is guaranteed. ${ }^{38}$

According to the Kurdistan Democratic Party,

The Educational Ladder in Iraqi Kurdistan consists of 2 years pre-school education for the $4-5$ years age group (not compulsory); 6 years compulsory primary education for 6-11 years; 6 years of secondary education of 2 cycles of 3 years each and higher education of $2-6$ years. ${ }^{39}$

All education, including university education, is free to students. Katarina Tomasevski, former United Nations Special Rapporteur on the Right to Education, in her report The State of the Right to Education Worldwide, examines education in 170 countries, determining to what extent education is free or fee-based. In more than half of these countries, fees are charged even for primary education. ${ }^{40}$ The global pattern of poverty-based exclusion from primary school is part of the global strategies for "no poverty reduction." Education is often priced out of the reach of the poor. The trend has been a transition from free and compulsory education to a market-based model in which the costs of even primary education have been transferred from government to family budgets. Against this background, South Kurdistan is remarkable.

For Kurdish children in Kurdistan today, Kurdish is the medium of education in all subjects. They also learn English as an obligatory subject in primary school. ${ }^{41}$ Assyrian-, Turkmen-, and Arabic-speaking children in Kurdistan are taught through Assyrian/Syriac, Turkmen, and Arabic and learn Kurdish and English as second or foreign languages. These minorities have their own departments in the Ministry of Education, each with its own director general. Meetings with some of these officials gave the impression that they are very satisfied with the current position of the minority groups in education, by comparison with earlier periods. ${ }^{42}$ There are also critical voices, however. ${ }^{43}$

Assyrian/Syriac, Armenian, Chaldean, Turkmen, and Arabic are taught as mother tongues. All these languages are also taught as elective subjects to those who want to learn them, while English and Kurdish (for non-Kurdish speakers) are obligatory as second or foreign languages. As mentioned above, the former minister of education, Abdul-Aziz Taib, formulated his conviction this way: "Every child in the world has the right to education through the medium of their mother tongue."44

Thus, in (Iraqi) Kurdistan, basic linguistic human rights ${ }^{45}$ are respected, both for Kurdish children (an earlier minority) and for most minority children:

1. Their mother tongues are accepted and respected.

2. They learn their mother tongues fully, as the mother tongue is the main language of instruction.

3. They are not forced to shift languages. 
4. They learn an official language. ${ }^{46}$

5. They can profit from education.

But, while signs of prosperity are palpable across Kurdistan, there are also signs of corruption, nepotism, patriarchal structures and attitudes, and, in general, poor governance. Also, as in the rest of Iraq, shortages of electricity and gasoline cause considerable hardship to large segments of the population. Furthermore, there is the issue of poverty. Despite rapid economic growth generated by local and foreign investments, many families still live below the poverty line. All this influences children's health, including food availability and intake.

The material quality of schools, teaching materials, and so on remains poor. Teacher training is traditional, and often authoritarian and inadequate, despite good intentions. Teaching through the medium of languages that have seldom or never been used in schools requires time, effort, and training, and no training in language planning is yet available. Both corpus planning and acquisition planning are badly needed. There is also a risk that inappropriate advice from American and British publishers and other bodies will be accepted, both by necessity and through a lack of awareness of various aspects of languages-in-education research and experience elsewhere. Nevertheless, good intentions and motivation are palpable. For example, children's literature, including periodicals published for children, are very much in evidence.

\section{A Comparison of the Two Situations in Terms of Linguistic Human Rights in Education}

All Kurdish children in Turkey are taught subtractively, in submersion (sink-or-swim) programs. Turkish is the language of instruction; children receive no education using Kurdish as the language of instruction, nor is Kurdish even taught as a subject. Subtractive teaching through the medium of a dominant language (i.e., using the dominant language as the language of instruction) replaces the children's mother tongue, subtracting from their linguistic repertoire. This is the situation for Kurds in Turkey.

Additive teaching through the medium of the mother tongue, with good teaching of the dominant language as a second language, adds to children's linguistic repertoire and makes them high-level bilinguals or multilinguals; they learn both their own language and other languages well. This is the situation for minorities in Iraqi Kurdistan. Kurdish children, a minority at the level of the Iraqi state, also have a positive situation in terms of learning their mother tongue, whereas their situation with respect to learning other languages remains unclear at the moment.

What does subtractive teaching do? It leads to forced assimilation. It is, in effect, genocidal, according to the definitions of genocide in art. 2 of the UN Convention on the Prevention and Punishment of the Crime of Genocide (UNCG):

In the present Convention, genocide means any of the following acts committed with intent to destroy, in whole or in part, a national, ethnical, racial or religious group, as such:

(a) Killing members of the group;

(b) Causing serious bodily or mental harm to members of the group;

(c) Deliberately inflicting on the group conditions of life calculated to bring about its physical destruction in whole or in part; 
(d) Imposing measures intended to prevent births within the group;

(e) Forcibly transferring children of the group to another group. ${ }^{47}$

The education offered to Kurdish children in Turkey is specifically a form of genocide according to arts. 2(e), "forcibly transferring children of the group to another group," and 2(b), "causing serious bodily or mental harm to members of the group."48 In this section we give a few examples, drawn from other parts of the world, of how education can contribute to genocide according to these two definitions. Pirjo Janulf's longitudinal large-scale study of ninth-grade Finnish children in Sweden, published in 1998, is one. These children received all their education through the medium of Swedish; no Finnish-medium classes were available at that point. After fifteen years, Janulf went back to as many of her original Finnish subjects in Sweden as she could find; she discovered that not one of them spoke any Finnish to their own children. ${ }^{49}$ Although they themselves may not have forgotten their Finnish completely, their children were certainly forcibly transferred to the majority group, at least linguistically. This is what Turkish education attempts to do to Kurdish children.

A 1998 Canadian report on Inuit children whose education has been through the medium of English states that "teenagers cannot converse fluently with their grandparents." 50 The same is true for many Kurdish children in Turkey. Assimilationist education is genocidal because it forcibly transfers children from their own group to another group, linguistically and culturally.

Edward Williams' 1995 study in Zambia and Malawi observed and tested some 1,500 students in first through seventh grades. The Zambian students received all their education in English from day one, whereas the Malawian children were taught in local languages, very often their mother tongues, for their first four years of school, with English as a separate subject, and switched over to English-medium teaching beginning in the fifth grade. Large numbers of Zambian pupils "have very weak or zero reading competence in two languages," Williams states, whereas the Malawian children had slightly better test results even in the English language than the Zambian students. In addition, they learned to read and write their own languages. Williams' conclusion is that "there is a clear risk that the policy of using English as a vehicular language may contribute to stunting, rather than promoting, academic and cognitive growth." 51 This is "causing serious mental harm" in the Genocide Convention's sense. Education of many Kurdish children in Turkey is also very likely to stunt rather than promote their cognitive and academic growth.

Another Canadian report on Inuit children in English-medium education, published in 1985, tells of Canadian Inuit "students who are neither fluent nor literate in either language" and "presents statistics showing that the students "end up at only Grade Four level of achievement after nine years of schooling." "52 According to Mick Mallon and Alexina Kublu, "a significant number of young people are not fully fluent in their languages," and many Inuit students "remain apathetic, often with minimal skills in both languages." 53 The same is likely true for many Kurdish children in Turkey.

Clearly, this subtractive, dominant-language-only-medium submersion model of education can cause serious mental harm to students from indigenous, minority, or dominated groups. It attempts, often successfully, to transfer them forcibly to another linguistic group. This is linguistic genocide.

To qualify as genocide, an act must be intentional. Have states acted with an intent to "forcibly transfer children of the group to another group" and to "cause serious bodily or mental harm to members of the group?" Yes-unfortunately, they have. 
As our earlier examples show, Turkey has certainly had, and still has, the intent to destroy the Kurdish language and identity. This intent has been and still is openly expressed in countless documents. ${ }^{54}$

Dominant-language-only submersion programs "are widely attested as the least effective educationally for minority language students" is using for Kurdish children. The negative results of subtractive teaching were already known at the end of the nineteenth century. States and educational authorities, including churches, have long been aware of this. ${ }^{56}$ Research results about how indigenous and minority education should be organized have been available for at least fifty years, since the publication of the UNESCO expert group's book The Use of Vernacular Languages in Education in 1953. If states, despite this evidence and despite very positive results from properly conducted additive teaching, continue to offer subtractive education, with no alternatives, knowing that the results are likely to be negative and thus to "transfer children" and "cause serious mental harm," this course of action must be seen as intentional.

What should Turkey do instead? We know from research that the longer indigenous and minority children in a low-status position have their own language as the main medium of teaching, the better they also do in the dominant language, provided, of course, that they are well taught in that language, preferably by bilingual teachers. If the Turkish state wants Kurdish children to learn Turkish well, the best way to accomplish this goal would be to use Kurdish as the main language of instruction and to teach Turkish as a subject, using teachers bilingual in Turkish and Kurdish. Schools in Turkey should minimally aim at competence in three languages:

1. for all, the mother tongue (Arabic, Armenian, Kurdish, Turkish, etc.);

2. for all minorities, the dominant state language (Turkish); for native Turkish speakers, a domestic minority language; and

3. for all, English (or some other major international language).

This type of education toward trilingualism is the aim of the system in (Iraqi) South Kurdistan, although they are still far from reaching it for all children. This model can be compared with the Indian three-language formula, with successes and failures. ${ }^{57}$

\section{Analyzing the "Contradiction"}

How can we understand the fact that the United States (with its coalition partners) supports and participates in enacting genocide (including linguistic and cultural genocide through in education) in Turkey while at the same time, first through the "safe haven" policy and now through occupation, partially enables respect for linguistic rights in education in Iraqi Kurdistan? In this section we analyze the seemingly contradictory US policy vis-à-vis the Kurds, including Kurdish language rights in education, with reference to three main goals: ${ }^{58}$

1. to secure oil, energy, and water deliveries, in a new situation of uncertainty, through Turkey and from Iraqi Kurdistan;

2. to secure support from Turkey in restructuring the Middle East; and

3. to secure new arms deals.

Before analyzing possible causes, however, we present some additional facts of the physical genocide and criticism of it in Turkey, of US involvement in it from the 1980s 
to 2007, and of the ideological prerequisites for enforced assimilation that have existed, and continue to exist, in both the United States and in Turkey.

\section{USA Involvement in Turkey: Actions, Intentions, Prerequisites}

At least some 4,000 Kurdish villages have been bombed, depopulated, and destroyed. ${ }^{59}$ More than three million Kurds are internally displaced; tens of thousands of Kurdswomen, men, and children-have been killed, raped, tortured, and genocidally subjected to "debasement" and "mental harm." ${ }^{60}$ Noam Chomsky has observed that

there was no "looking away" in the case of Turkey and the Kurds: Washington "looked right there," as did its allies, saw what was happening, and acted decisively to intensify the atrocities [against Kurds], particularly during the Clinton years. The US did not "fail to protect the Kurds" or "tolerate" the abuses they suffered anymore than Russia "fails to protect" the people of Grozny or "tolerates" their suffering. ${ }^{61}$

He continues,

The new generation of "humanitarian" western leaders drew the line by consciously putting as many guns as possible into the hands of the killers and torturers-not just guns, but jet planes, tanks, helicopter gunships, all the most advanced instruments of terror-sometimes in secret, because arms were sent in violation of congressional legislation. At no point was there any defensive purpose, nor any relation to the Cold War...In the case of the Kurds [in Turkey], helping them would interfere with US power interests. Accordingly, we cannot help them but must rather join in perpetrating atrocities against them. ${ }^{62}$

A disturbing testimony from a death-squad killer named Murat Ipek, if true, further suggests that US forces were directly involved in the training and coordination of some of the genocidal death squads: "An American ... controlled and instructed the contrateams." ${ }^{63}$ It has also been established that Huseyin Kocadag, chief of the Special Forces in Hakkari and deputy chief of police in Diyarbekir, who has been identified as "one of the most bloody enemies of the (Kurdish) people (and) who organised the units of the "head-hunters" in Kurdistan ... was trained at a CIA school in the US." ${ }^{64}$ The US administration and American intelligence agencies were also actively involved in facilitating the illegal capture and abduction of Abdullah Öcalan (chair of the PKK) in Kenya in $1999 .{ }^{65}$

Key concerns about human rights were raised in a 1993 UK Parliamentary Human Rights Group report:

The depopulation of the Kurdish region is, we believe, part of a deliberate strategy aimed not merely at eliminating a few thousand [PKK] guerrillas, but to extinguish the separate identity of the Kurdish people...In Britain, as elsewhere, the question of Turkish Kurdistan is often presented as one of a reasonably democratic government seeking to cope with an intractable problem of terrorism. We believe that the reality is one of military terrorists aiming to extinguish the identity of a people, and we were much alarmed by the parallel drawn with the Armenian holocaust of $1915-1916 .{ }^{66}$

The charge of genocide was clearly made by prominent organizations and individuals. For the international organization Article 19, the situation was all too apparent by 1997:

We believe there is now ample evidence to indict the Turkish Government of gross violations of human rights which constitute infringements of ... the UN Convention on the Prevention and Punishment of Genocide, amongst other treaties to which Turkey is a party. ${ }^{67}$ 
For Karen Parker, a lawyer and analyst in international and humanitarian law,

Turkey's actions [by 1999] clearly [met] the international law test for genocide: killing and causing serious bodily harm, inflicting conditions of life calculated to bring about its physical destruction in whole or in part (ethnic cleansing and other acts)...I am convinced that Turkey qualifies as a racist regime vis-à-vis the Kurdish people... The ethnic cleansing scheme, taking place in the context of the war, is both genocide and a war crime. $^{68}$

And according to Vijay Prasad, "the anti-Marxist and anti-communist flavour of Euro-America [has] enabled the Turks to continue a genocidal campaign to liquidate the Kurdish people." 69

In the post-9/11 period, under the cover of the global "War on Terror," the US government has continued to support the Turkish state in a highly questionable "anti-terrorism" offensive against Kurdish civilians, human-rights activists, peace campaigners, and "PKK militants" in the region. ${ }^{70}$ The Federal Bureau of Investigation (FBI), the Drug Enforcement Agency (DEA), US Special Forces, and other agencies have all extended "anti-terrorism"-related "assistance."71 Questionable US International Military Education Training (IMET) courses with Turkish forces have continued even as the US embassy in Ankara has confirmed that

General Joseph W. Ralston (USAF, retired) has been appointed as Special Envoy for Countering the PKK. General Ralston will have responsibility for coordinating US engagement with the Government of Turkey and the Government of Iraq to eliminate the terrorist threat of the PKK and other terrorist groups operating in northern Iraq and across the Turkey-Iraq border. ${ }^{72}$

In September 2006, General Ralston confirmed that

the United States would take tangible measures on the PKK,...adding that all measures would be taken for an influential fighting... He ruled out the possibility of meeting with [the] PKK... “... I never meet a terrorist organization. We want to get rid of them." ${ }^{\text {73 }}$

Nancy McEldowney, representing the US embassy at a September 11 commemoration service in Ankara in 2005, stated in her address that there was no difference between al-Qaeda and the PKK, or between Abdullah Öcalan and Osama Bin Laden. "Turkey and the United States' joint battle will continue," she said. "There will be no areas for them to retreat where Turkey and the US cannot go. Together we shall hunt the terrorists and destroy them."74

In this metaphor of "hunt" and "battle," which treats a minority's refusal to assimilate as an ideological challenge, the similarities between Turkey and the United States are striking. In the same way that the United States killed off or forcibly assimilated most of its indigenous peoples in order to profit from their land, water, and material resources, Turkey wants to eliminate the Kurds as a nation. In the same way that the United States does not tolerate other languages and cultures, seeing them as "un-American" and a threat to "Americanness," Turkey sees other languages and cultures as a threat to the integrity of the state and to its "Turkishness." When the United States aggressively supports the Turkish state's war against "PKK terrorists" (i.e., all Kurdish people who politically acknowledge aspects of their "Kurdishness"), the Turkish ideologies of genocide vis-à-vis the Kurds fit the physically genocidal (against indigenous peoples) and culturally and linguistically genocidal assimilationist (against immigrants) policies of the historical and present-day United States extremely well. Change "immigrant" to "Kurdish," "American" to "Turkish," and 
"English" to "Turkish" in the following statement, made by former US president Theodore Roosevelt in a 1919 letter to the president of the American Defense League, and we have the ideology that has prevailed in Turkey since 1923:

In the first place, we should insist that if the immigrant who comes here in good faith becomes an American and assimilates himself to us, he shall be treated on an exact equality with everyone else, for it is an outrage to discriminate against any such man because of creed, or birthplace, or origin. But this is predicated upon the person's becoming in every facet an American, and nothing but an American... There can be no divided allegiance here. Any man who says he is an American, but something else also, isn't an American at all. We have room for but one flag, the American flag... We have room for but one language here, and that is the English language ... and we have room for but one sole loyalty and that is a loyalty to the American people. ${ }^{75}$

Below we give a few examples of expressions of similar Turkish assimilationist ideologies, and of the policies and practices that put in place to realize the goals of the Kemalist state:

On March 3, 1924,... a decree banned all Kurdish schools, organizations, and publications, as well as religious fraternities and medressehs, which were the last source of education for most Kurds. Deportations of Kurds to the west [occurred] after the Sheikh Said rebellion was crushed in 1925. The purpose was to dilute the Kurdish population in order to facilitate its assimilation... Law No. 2510 in June 1934 sought further to disperse the Kurdish population to areas where it would constitute no more than 5 percent of the total. It was even suggested that Kurdish children be sent to boarding schools where they would speak exclusively in Turkish. ${ }^{76}$

On 4 May 1925, Turkish prime minister Ismet Inonu said,

Nationalism is our only factor of cohesion. Before the Turkish majority, other elements have no kind of influence. At any price, we must turkify the inhabitants of our land, and we will annihilate those who oppose Turks or "le Turquisme.""77

They were all Turks, [Mustafa Kemal Atatürk] told them, and for decades after his death that's how the Kurds were officially described-"Mountain Turks" who would be assimilated over time into "civilised society." Often, it was done by overwhelming force: military officers who led the campaign against the PKK in the 1980's and 1990's had plenty of historical parallels to emulate. ${ }^{78}$

And according to Mahmut Esat Bozhurt, Turkey's minister of justice, "Only the Turkish nation is entitled to claim ethnic and national rights in this country. No other element has any such right. ${ }^{79}$

Ismail Besikci writes,

In 1960, Mehmet Sherif Firat's book, Dogu Illeri ve Varto Tarihi was reprinted and distributed. This was another one of the books which claimed that there were no such people as Kurds, who were really Turks, and that Kurdish was a dialect of Turkish. Originally written in 1948, the 1960 reprint was widely distributed free of charge by the Ministry of Education to universities, professors, student associations, journalists, writers and school libraries. During this same period, numerous articles appeared, stating that the Kurds were Turks. Language experts bent over backwards trying to prove that Kurdish was a variant of Turkish. University professors lent all their efforts to the task. Numerous seminars and conferences were held. ${ }^{80}$

Further, as Michael Gunter reports,

During the 1960's, Turkish President Cemal Gursel lauded [this] book written by Sherif Firat... and helped to popularize the phrase "spit in the face of he who calls you a Kurd" as a way to make the word "Kurd" an insult. At the same time, Law No. 1587 furthered 
the process of changing Kurdish names, "which hurt public opinion and are not suitable for our national culture, moral values, traditions and customs," into Turkish names. ${ }^{81}$

Even as recently as 2002, an indictment against twenty-four students who had requested that Kurdish language classes be offered as elective courses at their university, submitted to the Security Court in the state of Van, claimed that

Teacher M. Serif Firat, in his work [mentioned above] ... has advocated and proved that the Kurds are of Turkish origin... The Turks and the Kurds...share the same language...Although this is the case today the separatist movement and its collaborators are endeavoring to create a separate language and a separate people... The demand for Kurdish education is not possible as regards the provisions of our Constitution. Our Constitution does not permit education in Kurdish. Article 3 of the Constitution states: The Turkish state, with its territory and nation, is an indivisible entity. Its language is Turkish... Article 4 states... [that] the provision of Article 3 may not be amended, nor may their amendment be proposed. The final paragraph of Article 42 states: No language other than Turkish may be taught as mother tongue to Turkish citizens at any institutions of training and education and the rules to be followed by schools conducting training and education in a foreign language shall be determined by law. ${ }^{82}$

According to Besikci,

The chief vehicles for assimilation have been the mass media and educational institutions. Every possible avenue has been tried to increase the influence of Turkish teaching in Kurdistan. From the early 1960s on, Regional Boarding Schools (Bolge Yatili Ilkokullar) began to be constructed in various regions of Kurdistan. Children who had reached primary school age were brought from their homes to study in an environment away from their families and villages. Such environments were conducive to assimilation because the children were permeated with Turkish language and ideology and had no contact with their native Kurdish culture whatsoever... The schools were kept under strict discipline. During the regimes of 12 March and 12 September, military officers were appointed as headmasters. The aim of all these measures was to ensure the full severance of individuals from their Kurdish environment. Following the coup of 12 September 1980, assimilation was once again placed on the agenda... The literary courses which were commenced ... were meant for the assimilation of Kurds...Coskun Kirca writes that "the separatists eager for independence, or the dreamers of autonomy, will be damned into seeing that no one has any other choice other than becoming a Turk or being absorbed into Turkhood." 83

Gérard Chaliand reports that "in 1966, Emin Bozarslan published an ABC for the Kurdish children of Turkey: the book was immediately banned." 84

As documented in a 1990 report by Helsinki Watch,

In May 1989, the National Security Council launched a campaign denying the existence of a distinct Kurdish nation and a Kurdish language. Pamphlets were issued and distributed to schools in the south-east, claiming that Kurdish is not a distinct language, but a dialect of Turkish. ${ }^{85}$

Professor Dr. Orhan Turkdogan has claimed that "there is no such thing as the Kurdish people or nation." 86 According to the late Alparslan Turkes, general secretary of the National Action Party, "Turkey is not a cultural mosaic, everyone in Turkey is a Turk." 87 Speaking of the Kurdish language, Oltan Sungurlu, Turkey's minister of justice, is quoted as saying, "What language is that? I do not know of such a language." $" 88$

Alpaslan Pehlivanli, chairman of the Justice Committee in the Turkish parliament, argued that 
if the word "language" now in the bill [aimed at repealing Law 2932 in order to legalize the use of Kurdish "in a rather limited way"] stays in, we will have admitted that the Kurds are a nation... If it passes this way, tomorrow there will be cafes where Kurdish folk songs are sung, theatres where Kurdish films will be shown, and coffee houses where Kurdish is spoken. If this is not separatism, then what is? ${ }^{89}$

Similarly, Gunter writes,

Justifying its refusal to grant any concessions, the Turkish military argued that: “...Even pursuing language rights for the Kurds in Turkey... is to be regarded as serving the PKK's ['terrorist'] interests. Period."90

And in 1995,

General Ahmet Corekci, the vice chief of staff, ... [argued] that demands for Kurdish language and education rights were part of the "salami tactic... the more slices we cut the more they will take."91

\section{As Chris Morris reports,}

In 2001 a Turkish court banned the Batman city council from using Kurdish words as street names... The highest administrative court in the land ruled that the names... could ... lead to an "erosion of cultural values"... Even newborn children have not been immune. In 2002 parents... found themselves being warned that giving a child a Kurdish name would be "interpreted as terrorist propaganda." Children should be named, as Interior Ministry directive warned, "in a manner appropriate to our national culture, moral principles and customs"... In March 2005 the Environment and Forestry Ministry in Ankara proudly announced that it was changing the Latin names of some indigenous animals to eliminate references to Kurdistan and Armenia. ${ }^{92}$

Morris has perceptively concluded that "since the formation of the republic, Turkey has grudgingly accepted a narrow definition of non-Muslim religious minorities, but it's never been prepared to accept linguistic or ethnic ones (sorry, all you Kurds)."93 This explains why educational language policy remains linguistically genocidal in its nature and scope. The example he cites is instructive:

When a report calling for radical change in mentality was written by an advisory group within the Prime Ministry, there was uproar. "The citizens the state should fear the least," argued the discredited report, "are the ones who have been granted their rights." If that means diluting the idea of Turkishness, though, it is still too much for most people in power. The AKP government hastily disowned the recommendations, a senior general growled with displeasure, and a copy of the report was torn up at a news conference which had been called to publicise it. ${ }^{94}$

In light of these examples of actions, intentions, and ideological prerequisites that the USA and Turkey seem, to a large extent, to share, we go back to the "Whys," the three causal factors that are part of an explanation of the United States' (and its coalition partners') direct or indirect support of the different language-in-education models in Turkey and Iraqi Kurdistan.

\section{Oil, Energy, and Water}

The first "why" linked to the United States, and to its coalition partner the United Kingdom, has to do with securing the delivery of oil, energy, and water. The Baku-Tbilisi-Ceyhan (BTC) oil pipeline, which began operating in 2006, is a key US-backed initiative aimed at cutting out Russian influence in the exploitation of Caucasus-linked oil. Turkey has developed the critical link in the project that key US-UK oil giants (Unocal, ConocoPhillips, Amerada Hess, British Petroleum) are 
involved in: "The Baku-Tbilisi-Ceyhan oil pipeline is being developed by a consortium of oil companies led by British oil giant BP." "95 Thus Turkey is a key pivot state whose cooperation is necessary to facilitate this US/UK-backed mega-project:

The Baku-Tbilisi-Ceyhan pipeline...transports crude oil $1,776 \mathrm{~km}$ from the AzeriChirag-Guneshli oil field in the Caspian Sea to the Mediterranean Sea. Total length in ... Turkey is $1076 \mathrm{~km}$... Baku-Tbilisi-Ceyhan is a politically driven project to create a pipeline that does not transit any of the territory of the post-soviet states that do not have warm relations with the west. ${ }^{96}$

Turkey also figures centrally in US neoconservative and Israeli state plans aimed at securing critical control of, and access to, other key oil, energy, and water resources in the region. ${ }^{97}$ According to a report in the Jerusalem Post, in May 2006 Turkey and Israel were clearly

negotiating the construction of a multi-million-dollar energy and water project... The new Turkish-Israeli proposal under discussion would see the transfer of water, electricity, natural gas and oil to Israel via four underwater pipelines. "The whole premise is based on the assumption that Turkey is becoming a major hub for energy in the region," said Gabby Levy, the Director of International Relations at the National Infrastructure Ministry. The water would be earmarked for Israel as well as for the Palestinian territories and Jordan. ${ }^{98}$

In this situation, US administrations, in seeking to realize their geostrategic and economic aims, have agreed to support the anti-Kurdish ideological position of the Turkish state under the cover of the "War on Terror."

Why has there been a different response to the situation of the Kurds in northern Iraq? The United States' relations with "friendly" Middle East states that are sure to provide future oil delivery have been, and continue to be, unpredictable. This is part of the explanation for the relationship with Iraqi Kurdistan. The Kurdistan Regional Government (KRG) can and will be a reliable source, especially given the recent new discoveries of oil. Since South Kurdistan is in an extremely vulnerable situation, surrounded as it is by Turkey, Iran, and Syria, none of which wish their Kurdish minorities to present demands for more autonomy, friendly relations with the United States are vital for the KRG. Such relations may also include future military cooperation, air bases, and/or a commitment to assist the US and Turkish governments in their war against the "terrorist PKK." In return, the United States must accept, among other things, the strong position of Kurdish in Kurdistan.

But tensions exist. In the past, at the request of Turkey, the US government has allowed significant Turkish military incursions and bombing raids to take place in northern Iraq. William Hartung, in 1995, confirmed that

\begin{abstract}
the Turkish government's March 1995 invasion of Northern Iraq mark[ed] the latest chapter in its quest for a military solution to the Kurdish question. A Turkish government spokesperson proudly described the cross-border raid by 35,000 troops as "the biggest military operation in the history of the Turkish Republic."...Turkish Prime Minister Tansu Ciller cleared the operation with President Clinton by telephone before sending her military forces into Iraq... President Clinton and the Pentagon also ordered U.S. military personnel in Northern Iraq to "stand down" from enforcing the no fly zone against Turkish aircraft for the duration of Turkey's intervention. ${ }^{100}$
\end{abstract}

In 1991, "under pressure from the United States and Turkey, Iraqi Kurds had agreed to fight the PKK." 101 Since then, US administrations have continued to provide clearance for further Turkish military "incursions" and bombing raids (which have taken civilian lives) against PKK "forces." Today, however, the KRG is opposed to any 
major Turkish military incursion into northern Iraq that takes place without its permission. The KRG expects support from the US government in this matter, even as certain military and political circles in Turkey are pressing for US support for their own plans. Some fear that the KRG's educational policy is dependent upon a US government stance that will prevent any major Turkish military occupation force from settling and determining policy for the region.

\section{Restructuring the Middle East}

It is vital for the United States to secure Turkey's support in the US restructuring of the Middle East and other regions. Some of the relevant issues are as follows:

- Turkey is a key NATO ally.

- Turkey has provided crucial military assistance to the United States in many of its questionable recent interventions. For example, Turkish F-16s (purchased from the United States) were used in US/NATO-linked bombing missions in Serbia. $^{102}$

- Turkey was one of the countries that recently sent troops to Afghanistan, and there have been proposals to send Turkish "peacekeeping forces" into Lebanon. It also promises to assist the United States in several potential future conflicts elsewhere in its capacity as a member of NATO.

- Turkey is geostrategically a "pivot state" for the United States and Israel, and thus a key US ally, especially with the neoconservatives in power.

The aims of CIA Director Porter Goss's visit to Ankara in December 2005 possibly included, according to some analysts, securing:

- support for US policy against Iran's nuclear activities

- support for US policy to prevent Iran's support for "terrorist organizations"

- air bases for US operations against Iran and Syria

In return, the United States has had to commit, once again, to aggressive support of the Turkish state in its war against "PKK terrorists" in the southeast of the country in particular (i.e., in Northwest Kurdistan). In Iraqi South Kurdistan, however, because of the need to secure the stabilizing support of the KRG in a country where US forces are increasingly stretched by the occupation and where the KRG promises to keep the oil-rich area secure for Western exploitation, the US government has, thus far, not sought to act against the educational policies being promoted there. ${ }^{103}$

\section{Arms}

The actions, intentions, and methods of the United States have had their most concrete expression in connection with arms, including gifts of arms to Turkey, often through NATO; training of Turkish forces; and participation in Turkey's genocidal actions against Kurds. But the world's largest manufacturer and seller of arms obviously "needs" markets for its arms, and is manufacturing these markets as intensively as it manufactures the weapons themselves.

In 1992 and 1993, the Pentagon quietly facilitated a mammoth military shipment to Turkey at no cost. According to the UN arms registry, the US government turned over 1,509 tanks, fifty-four fighter planes, and twenty-eight heavily armed attack helicopters to Turkey. The weapons were slated for reduction after the Cold War under a 1990 treaty on conventional forces in Europe; instead of scrapping them, however, the United States simply gave them away. There was no congressional oversight of or 
public debate about the transfer, nor was there much question about the purpose of this unprecedented arms shipment. As Jane's Defence Weekly revealed as early as 1993 ,

"a high proportion of defense equipment supplied to Turkey is being used in operations against the PKK"... Military assistance to Turkey has even included the use of American soldiers... Hartung estimates US taxpayers... paid "tens of millions of dollars" to train Turkish forces to fight the Kurds. ${ }^{104}$

In October 2006, the New York Times described how the Pentagon continues to run this

little-publicized giveaway and tag sale program to clean out its overstuffed attics and closets, bulging with the greatest weapons buildup since the Reagan era. The Pentagon also uses the Excess Defense Articles program, as it is called, to reward government friends and allies across the globe. There are deals galore, available free to the right customer or for cents on the dollar of their original cost. There are lots of deal hunters, but access is by invitation only, and only for governments. ${ }^{105}$

This is a good way of getting the "friendly governments" hooked on continuing to buy the arms that they first got for free, or at massive price reductions. The list of such governments includes Turkey, now a very good customer.

In terms of arms provision, Lockheed Martin's F-16 fighter jets were "needed" during Turkey's genocidal war in the 1990s because of their usefulness in obliterating Kurdish settlements and in killing and terrifying Kurdish civilians:

It is widely known that the Turkish military... used Lockheed Martin F-16's to assist with the obliteration of Kurdish villages in North Kurdistan during the 1990's Dirty War, with the facts well-documented by human rights groups. In 1995, Human Rights Watch documented arms sales to Turkey, along with related violations of the laws of war by that state. Included among the many gross abuses that Turkey ... perpetrated against the Kurdish people, the F-16 fighter jet figure[d] prominently. ${ }^{106}$

The arms trade and the training of Turkish forces by Americans (and Israelis) was ongoing as of $2006:^{107}$

The Pentagon has notified Congress [that] it plans to allow Turkey [within the context of its "defense" needs] to buy 30 [more] F-16 fighter jets and related equipment, a $\$ 2.9$ billion deal that would provide new work for Lockheed Martin Aeronautics Co.'s Fort Worth assembly plant. ${ }^{108}$

Lockheed Martin is the world's largest arms manufacturer. "This proposed sale" in 2006, the US Defence Agency has claimed, "will enhance the Turkish Air Force's ability to defend Turkey"-no doubt against the internal Kurdish "threat" in the southeast, and the external one in southern Kurdistan/northern Iraq-"while patrolling the nation's extensive coastline and borders against future threats and to contribute to the Global War on Terrorism and NATO operations." ${ }^{109}$ General Joseph W. Ralston, the US government's special envoy responsible for countering the "terrorist" PKK and coordinating "actions" and "eliminationist strategies" with the Turkish and Iraqi states, happens to be "a member of the Board of Directors of Lockheed Martin, the same corporation whose deal for the sale of 30 F-16's [to Turkey] sits in the venerable halls of Congress at this very moment." 110

Indeed,

Ralston's appointment came at a time when Turkey was finalizing the sale of the $\$ 2.9$ billion 30 Lockheed Martin F-16 aircraft, and as Turkey was due to make a decision on the $\$ 10$ billion purchase of the new Lockheed Martin F-35 JSF aircraft. 
The sale for the F-16's was approved by Congress in mid-October [2006], and Turkey's decision in favor of the F-35 JSF was announced on October 25, shortly after Ralston's recent stay in Ankara, ostensibly to counter the PKK. ${ }^{111}$

Without a US-backed "War on Terror" in this region against Kurds and the PKK, and with a meaningful PKK-linked peace initiative making headway, as George W. Bush, the neoconservatives, and US arms traders and death-dealers well know, billions of dollars' worth of weapons deals with Turkey stand to be lost. And we couldn't have that, could we?

It looks like Lockheed Martin is going to guarantee the failure of the PKK ceasefire, because of a conflict of interest... You see, Lockheed Martin has an insider on its board of directors, and that insider is none other than the new US PKK coordinator, Joseph Ralston, also of the Cohen Group... The conflict of interest becomes more obscene by the fact that both Joseph Ralston and Lockheed Martin are closely tied to the Turkish lobby organization, the American Turkish Council (ATC). Joseph Ralston is a member of the 2006 ATC Advisory Board, while a former Lockheed Martin executive, George Perlman, is a member of the 2006 ATC Officers and Board of Directors. Lockheed Martin Corporation is a Golden Horn member of the ATC, as is General Electric Company, Boeing Corporation, Raytheon, and BAE Systems, all of which stand to profit from the current sale. This conflict of interest makes it clear that neither the US nor Turkey has the intention of finding a just and peaceful solution to the great opportunity the PKK ceasefire affords them. On the contrary, both countries seek a return to the Dirty War, in order to reap the profits of repression. ${ }^{112}$

The reactions of General Ralston and of the entire Turkish establishment, from General Büyükanıt to Prime Minister Erdogan, to the ceasefire proclaimed by PKK starting on 1 October 2006 have, predictably, been almost identical. The ceasefire has little value; the "terrorist group" should lay down its arms unilaterally; a ceasefire implies a relationship between two states, and PKK is a terrorist organization, not a state. In essence, their stance is that there will be no negotiations with "terrorists."

The stance of the UK, another member of the "coalition of the willing," has been just as questionable. Chomsky has referred to the "righteous terror and ethnic cleansing that ([Tony] Blair's) government and its allies" have helped "to implement within NATO" (i.e., in Turkey). ${ }^{113}$ William Clark wrote in 1999 that "the UK government is happy with the Turkish state, and has supported the war against the Kurds... The...UK's record on Kurdish issues proves it has contributed to and supported the genocidal war against them by Turkey."114 According to lawyer Gareth Peirce,

the British and Turkish governments, under the rubric of "suppression of terrorism," have [even] managed to criminalize the ("Turkish") Kurdish (refugee) community of Great Britain. Without engaging the legitimacy of a Kurdish struggle for national rights, the British police has deliberately worked to cast doubt on every Kurd in the UK as terrorist suspects. ${ }^{115}$

The program of assisting with the criminalization of the ("Turkish") Kurds is clearly being used to advance the geo-strategic, anti-PKK psychological warfare operational interests of two of Britain's NATO partners and allies-Turkey and the United Statesas well as the agendas of the G7/8 Terrorism Summit ${ }^{116}$ and the European Union's K4/ Europol and Schengen states. ${ }^{117}$ In return for such support, the British government has been able to secure lucrative arms, construction, privatization, and oil deals for British companies (including BP, a key party in the BTC pipeline project), as well as a number of its own geo-strategic objectives in the Near East, the United States, and Europe. 


\section{Northern Iraq and the Question of "Stability" in the Region}

In the debate over the restructuring of the Middle East, the KRG has sought to emphasize its pivotal significance to the US administration since 2003. Portraying itself as the one relatively stable and dependable region of Iraq, capable of promoting US interests in the country and in the wider region, the KRG has suggested that its existence and its support are essential. Any threat-such as that brought about by a major Turkish military invasion and occupation-will lead to defensive actions, heightened conflict, and the destabilization of an oil-rich zone that is critical to US interests and to American geopolitical designs. KRG President Massoud Barzani, seeking to dissuade Turkey's generals from invading South Kurdistan (in northern Iraq), has warned that any such action will also lead to turmoil in southeastern Turkey. In response, Turkey's chief of general staff, General Büyükanıt, "said he had already sought government approval to mount military action. 'We told both Turkey and the world on April 12 [2007] that as soldiers we are ready." "118 At the end of May 2007, Büyükanıt further

hinted at military action against Iraqi Kurdish leader Massoud Barzani and the... Kurdistan Workers' Party (PKK) in northern Iraq if the [Turkish] government formally requests a cross-border operation. "Are we going to fight only the PKK once we enter northern Iraq or will something happen with Barzani?” Büyükanıt asked. ${ }^{119}$

Lale Sariibrahimoglu, furthermore, confirms that retired general Edip Başer, "the appointed Turkish coordinator in the fight against the PKK, told news station CNN Turk on March 9 [2007] that Turkey's priority strategically has been to prevent the establishment of a Kurdish state in northern Iraq rather than the fight against PKK terror. Though I found his statement odd, Gen. Başer was at least admitting Turkey's real concerns" 120 and agendas. For Yilmaz, "Baser is expressing the view consistent with Henri Barkey's analysis from 2005 ... It's not only the prevention of an independent Kurdish state in South Kurdistan that the Ankara regime opposes, but control of Kerkuk is also a major issue."121

While some commentators have argued that the policies and practices of the KRG could serve as a model for the rest of Iraq and the Middle East—for example, in terms of promoting "progressive" educational policies alongside other "democratizing" policies aimed at promoting "stability," "security," and "economic growth"122_others have cautioned against taking such a stance. The KRG's educational language policies may be praiseworthy in many respects, but other policies and practices have drawn concern from a number of quarters. According to a 2007 UN report,

journalists in Iraq's autonomous Kurdistan region face arrest and harassment for reporting on government corruption and poor public services... The United Nations also criticised Kurdish officials for failing to tackle frequent cases of "honour killings" of women ${ }^{123}$ and said hundreds of detainees in Kurdish prisons were being held without charge ... UNAMI [the United Nations Assistance Mission in Iraq] . . . said it continually received reports about domestic and communal violence which were largely ignored by the Kurdish authorities... The report said UNAMI had received allegations of torture or ill-treatment of detainees at government detention centres. ${ }^{124}$

Another 2007 report-Incipient Genocide: The Ethnic Cleansing of the Assyrians of Iraq, by Peter BetBasoo-details the following concerns:

The 2007 report of the United States Commission on International Religious Freedom (USCIRF) describes Kurdish treatment of Assyrians in North Iraq: "Government complicity in religiously-motivated discrimination is also reported in 
the pro-Western...KRG. According to the State Department, Christians and other minorities 'living in areas north of Mosul asserted that the KRG confiscated their property... without compensation and...Assyrian Christians also alleged that the Kurdish Democratic Party-dominated judiciary routinely discriminates against nonMuslims.' Chaldo-Assyrian Christians have also alleged that KRG officials affiliated with the Kurdistan Democratic Party deny Christians key social benefits, including employment and housing."

... On October 8, 2002 the Kurdish Parliament of north Iraq adopted a resolution... The practical effect... was to legally transfer Assyrian lands that were illegally confiscated to Kurdish persons...Assyrian villages are [also] targeted by Kurds. The USCIRF report states: "Additional reports also alleged that foreign reconstruction assistance for ChaldoAssyrian communities was being controlled by the KRG without input from that community's legitimate leaders. KRG officials were also reported to have used public works projects to divert water and other vital resources from ChaldoAssyrian to Kurdish communities. These deprivations reportedly threatened the safety of ChaldoAssyrians leading to mass exodus, which was later followed by the seizure and conversion of abandoned ChaldoAssyrian property by the local Kurdish population... Combined with non-state sources of instability,... the KRG's practices add to the continuing flight of Iraq Christians and other ethnic and religious minorities to sanctuaries outside the country." 125

In the main, these worries seem well documented, even if the situation for Assyrians is much worse in the rest of Iraq. But there have also been accusations about linguistic oppression of Assyrians for which the evidence is less than strong. ${ }^{126}$

Reality is complex. Stability, in today's world, is always contextualized, both historically and globally. As long as outside interests frame the maneuvering space for both Kurds and other players in the Near and Middle East, cynically engaging in imperialist adventures (or misadventures) that leave devastation in their wake, and as long as the historically developed internal power relations favor domestic and patriarchal elites, regardless of their ethnicity, who are more or less intent on power sharing, positive models will remain scarce. In this context, KRG policies that seek to promote the right to education for all "through the medium of one's mother tongue" deserve our support and recognition, even as those that violate any group's human, cultural, or political rights urgently need to be confronted and addressed.

\section{Conclusion: Oil, Arms Deals, and Political Control-Forget about Democracy, Human Rights, and the Rule of Law}

In the words of George Kennan, the main US negotiator at Bretton Woods, where the World Bank and the International Monetary Fund were put in place, the United States in $1948 \mathrm{had}$

$50 \%$ of the world's wealth, but only $6.3 \%$ of its population. In this situation, our real job in the coming period is to devise a pattern of relationships which permit us to maintain this position of disparity. To do so, we have to dispense with all sentimentality... we should cease thinking about human rights, the raising of living standards, and democratization. ${ }^{127}$

Old US foreign policy thus continues today. Noam Chomsky's view on the United States is that it represents industrial feudalism rather than industrial democracy. ${ }^{128}$ Without the millions of undocumented ("illegal") immigrants whose rights are almost non-existent, like serfs under feudalism, US (industrial) agriculture would not be able to function, and neither would many other areas of the economy that feature difficult working conditions and minimal salaries. ${ }^{129}$ Some aspects of the governing 
structures of today's Turkey (the "deep state"130) might be seen as representing military-economic corporatism. ${ }^{131}$

Kurds cannot expect any support from Britain either-Tony Blair expects them to "acquiesce" in their treatment: "A top-secret memo seen by The Sunday Telegraph, reveals [that] Tony Blair and his senior officials have drawn up an extraordinary 'wish list' of how they would like to see the world looking just 10 years from now... A contentious section deals with the Kurdish populations of Turkey, Iran and Iraq, all of whom face repression. To avoid being seed beds for terrorism, these populations must be acquiescing in their treatment," wrote Patrick Hennessy, political editor of the Sunday Telegraph, in a 2006 article. ${ }^{132}$

Is there a future for the Kurds in Turkey? If they face a combination of Turkey's military-economic corporatism and the United States' industrial feudalism, while the United Kingdom's best-case scenario is that they "must be acquiescing in their treatment," a positive outcome seems, at best, uncertain. Maintaining and supporting diversity is a prerequisite for stability; denial of linguistic and cultural human rights leads to conflict, and conflicts are expensive, politically and economically, as well as in terms of human suffering. Respect for linguistic and cultural human rights generally leads to stable coexistence and increased harmony-and this is what should be supported and encouraged in (Iraqi) South Kurdistan. We can see some substantive beginnings of this policy as it applies to linguistic human rights in South Kurdistan, however weak, problematic, and vulnerable. The issue of discriminatory practices against Assyrians in the north and south of Iraq urgently needs to be addressed. Meanwhile, Turkey and the United States, with help from the United Kingdom and other EU and NATO countries, through their genocidal activities or acceptance of same, are actively preventing peace in Turkish Kurdistan and destroying the Kurds.

We should remember the words of Mahatma Gandhi: "The cause of liberty becomes a mockery if the price to be paid is the wholesale destruction of those who are to enjoy liberty." 133

\section{Acknowledgments}

This article is based on our joint presentation at the conference Dialogue Under Occupation: The Discourse of Enactment, Transaction, Reaction, and Resolution, 7-11 November 2006, Northeastern Illinois University, Chicago. Desmond Fernandes would like to thank Iskender Özden, Miranda Watson, Selahattin Celik, Estella Schmidt, Mızgîn Yilmaz, Anthony Tingle, William Clark, and Ali Çiftçi. Dozens of Kurdish and other friends have taught Tove Skutnabb-Kangas about the Kurdish situation, some throughout the last thirty years: thanks! A few: Gülda Bozarslan, Mehmet Emin Bozarslan, Sertaç Bucak, Mahmut Erdem, Hassan Ghazi, Amir Hassanpour, Şevki Huseyin Kizilocak, Kristiina Koivunen, Shahrzad Mojab, Mueyed Taib, and Abdul-Aziz Taib. Some of the present-day (Iraqi) South Kurdistan data was gathered during TSK's almost-two-week visit in March 2006, as a guest of the then minister of education, Abdul-Aziz Taib. Thanks!

\section{Notes}

1. K. Koivunen, "The Invisible War in North Kurdistan" (PhD diss., University of Helsinki, 2002); Desmond Fernandes, Colonial Genocides in Turkey, Kenya and Goa (Stockholm: Apec Books, forthcoming); Desmond Fernandes, The Kurdish Genocide in Turkey (Stockholm: Apec Books, forthcoming). 
2. Tove Skutnabb-Kangas, "Human Rights in Education and Turkey-Some International Comparisons" (invited plenary paper presented at the International Conference on Kurds, the European Union and Turkey, Copenhagen, Denmark, 14 October 2002), http:// www.kurds.dk/english/2000/news115.html (accessed 9 January 2008); Convention on the Prevention and Punishment of the Crime of Genocide, 9 December 1948, 78 U.N.T.S. 277, http://www.unhchr.ch/html/menu3/b/p_genoci.htm (accessed 9 January 2008).

3. The Web site of the Kurdistan Regional Government can be accessed at http:// www.krg.org/ (accessed 9 January 2008).

4. Abdul-Aziz Taib (minister of education, Kurdistan Regional Government), interview by Tove Skutnabb-Kangas, 15 and 17 March 2006, Hawler/Erbil, Iraqi Kurdistan.

5. Desmond Fernandes, "The Kurdish Genocide in Turkey, 1924-98," Armenian Forum 4 (1999): 57-107; Desmond Fernandes, “Turkey's US Backed 'War on Terror': A Cause for Concern?" Variant: Cross Currents in Culture 27 (2006), http://variant.randomstate.org/ 27texts/cause_for_concern.html, http://variant.randomstate.org/pdfs/issue27/Variant27TURKEY_US_WOT.pdf (accessed 25 August 2007); Desmond Fernandes, The Kurdish and Armenian Genocides: From Censorship and Denial to Recognition? (Stockholm: Apec Books, 2007); Desmond Fernandes, "On Genocide Denialism, Guenter Lewy, the Nature of Representation/Misrepresentation, and His 'Interpretation' and 'Presentation' of 'Evidence'" (paper presented at the conference Presentation of Evidence of the Armenian Genocide, London, 24 April 2007); Fernandes, Colonial Genocides; Fernandes, The Kurdish Genocide; Desmond Fernandes, Perspectives on the Armenian, Assyrian, Pontic Greek and Kurdish Genocides (Stockholm: Apec Books, forthcoming); Desmond Fernandes, US, UK, German, Israeli and NATO "Inspired" Psychological Warfare Operations against the Kurdish "Communist" Threat in Turkey and Northern Iraq (Stockholm: Apec Books, forthcoming); Tove Skutnabb-Kangas, Linguistic Genocide in Education, Or, Worldwide Diversity and Human Rights? (Mahwah, NJ: Lawrence Erlbaum, 2000); Skutnabb-Kangas, "Human Rights in Education"; Tove Skutnabb-Kangas, "Tehlike Altındaki Dilsel ve Kültürel Çeşitlilik ve Tehlike Altındaki Biyoçeşitlilik—Çeşitliliğin Korunmasında Dilsel İnsan Hakları Eğitiminin Rolü," Bîr. Kovera lêgerîn û lêkolînê. Aroçtirmo-İnceleme dergisi 3 (2005): 7-37; Tove Skutnabb-Kangas, "Endangered Linguistic and Cultural Diversities and Endangered Biodiversity - the Role of Educational Linguistic Human Rights in Diversity Maintenance," http://www.sert.pen-kurd.org/Diyarbakir-seminar/toveendangered-linguistic-and-cultural-diversities.html (accessed 7 September 2007); Tove Skutnabb-Kangas, "Eğitimde Dilsel ve Kültürel Çeşitlilik İnsan Hakları ve TürkiyeUluslararası Bazı Karılaş İtırmalar," Bîr. Kovera lêgerîn û lêkolînê. Aroçtirmo-İnceleme dergisi 3 (2005): 38-62; Tove Skutnabb-Kangas, "Language Rights and Bilingual Education," in Encyclopedia of Language and Education, Vol. 5: Bilingual Education, ed. Jim Cummins and Nancy Hornberger, 117-31 (Dordrecht: Kluwer Academic Publishers, 2008); Tove Skutnabb-Kangas and Sertaç Bucak, "Killing a Mother Tongue-How the Kurds Are Deprived of Linguistic Human Rights," in Linguistic Human Rights: Overcoming Linguistic Discrimination, ed. Tove Skutnabb-Kangas and Robert Phillipson with Mart Rannut, 347-70 (Berlin: Mouton de Gruyter, 1994); Tove SkutnabbKangas and Robert Phillipson, "Kurdisch-eine verbotene Sprache. Wie die Kurden in der Türkei sprachlicher Menschenrechte beraubt werden," Informationsbulletin Kurdistan 31 (1990): 3-8; Tove Skutnabb-Kangas and Robert Phillipson, "Linguistic Genocide and Human Rights-Kurdish Considerations," in The Kurds: Perspectives on a Unique Culture, ed. Petra Sundqvist, 25-48 (Helsinki: Suomen Rauhanliitto YK-Yhdistys, 1999); Amir Hassanpour, Khaled Salih, Jaffer Sheyholislami, and Tove Skutnabb-Kangas, eds., Kurdistan and Survival of a Nation: From Genocide to Rights. Language, Education and Identity (Clevedon, UK: Multilingual Matters, forthcoming).

6. Amir Hassanpour, Nationalism and Language in Kurdistan, 1918-1985 (San Francisco: Mellen Research University Press, 1992), 12; Kendal, "Kurdistan in Turkey," in A People Without A Country: The Kurds and Kurdistan, ed. Gerard Chaliand, 38-94 
(London: Zed Books, 1993), 39; Borhanedin A. Yassin, Vision or Reality? The Kurds in the Policy of the Great Powers, 1941-1947 (Lund: Lund University Press, 1995), 37.

7. David McDowall, The Kurds (London: Minority Rights Group, 1991), 9.

8. E.g., Laure Almairac and Paula Tscherne-Lempiäinen, eds., Turkey: A Minority Policy of Systematic Negation (Vienna: International Helsinki Federation for Human Rights, October 2006), 12.

9. Wikipedia, s.v. "Kurdish People," http://en.wikipedia.org/wiki/Kurdish_people (accessed 25 October 2006).

10. For all these countries see The Kurdish Diaspora (Paris: Institut Kurde de Paris, 2006), http://www.institutkurde.org/en/kurdorama/ (accessed 25 October 2006).

11. Lokman I. Meho, "The Kurds and Kurdistan: A General Background," in Kurdish Culture and Society: An Annotated Bibliography, comp. Lokman I. Meho and Kelly Maglaughlin, 3-26 (Westport, CT: Greenwood Press, 2000), 4.

12. Wikipedia's estimate of 60,000, from Radio Sweden International's Kurdish program, is too high; we use here the estimate given in Amir Hassanpour and Shahrzad Mojab, "Kurdish Diaspora," in Encyclopedia of Diasporas: Immigrant and Refugee Cultures around the World, ed. M. Ember, C.R. Ember, and I. Skoggard, 214-24 (New York: Kluwer Academic, 2005).

13. "Kurds in Georgia," in Eurominority: Portal of European Stateless Nations and Minorities (Quimper, France: Organization for the European Minorities, 2006), http:// www.eurominority.org (accessed 25 October 2006); The Kurdish Diaspora.

14. NZZ, 20 September 2002, quoted in International Association for Human Rights of the Kurds [IAHRK], "Kurdish Tuition Permitted in Turkey: Bureaucratic Hurdles to Prevent Language," IMK Weekly Information Service 168 (17-25 September 2002), http://www.kurds.dk/english/2000/news114.html (accessed 9 January 2008).

15. Mariam Carrion Benitez and David Lawson, The Trial of Students: "Tomorrow the Kurdish Language Will Be Prosecuted..." (London: Kurdish Human Rights Project, 2002), 7.

16. Evrensel, 14 August 2002, cited in IAHRK, "Teachers Before Court," IMK Weekly Information Service 165 (14-22 August 2002), http://www.kurds.dk/english/2000/ news112.html (accessed 10 January 2008).

17. Hurriyet, 11 June 2002, cited in IAHRK, "27 Children Brought Before Diyar-bakir's State Security Court," IMK Weekly Information Service 160 (17-28 June 2002), http://www.kurds.dk/english/2000/news107.html (accessed 10 January 2008).

18. Aram Publisher, "Conspiracy and Crisis: Turkey and the Kurdish Question: From the Nineties to the Present Day," ZNet Policy Watch, 22 January 2002, http://www.zmag.org/content/ForeignPolicy/aram0122.cfm (accessed 10 January 2008).

19. Jon Rud, "Turkey's Implementation of European Human Rights Standards-Legislation and Practice," in EU Turkey Civic Commission: International Conference on Turkey, the Kurds and the EU, European Parliament, Brussels, 22-23 November 2004-Conference Papers, ed. Mark Muller, Claire Brigham, Kariane Westrheim, and Kerim Yildiz, 53-70 (London: Kurdish Human Rights Project [KHRP], 2005), 65.

20. “Ten Local TVs Queued for Kurdish Broadcast," BIA News Center, 25 August 2005.

21. Yedinci Gündem, 12 May 2002, cited in IAHRK, "Kurdish Tuition as Grounds for Torture," IMK Weekly Information Service 156 (13-24 May 2002), http://www.kurds.dk/ english/2000/news102.html (accessed 10 January 2008).

22. Evrensel-TIHV, 6 April 2004, cited in Info Turk, "Members of a Music Group on Trial in Diyarbakir," Info Turk 308, April 2004, http://www.info-turk.be/ 308.htm\#Members\%20of\%20a\%20Music\%20Group\%20on\%20Trial\%20in\%20Diyarbakir (accessed 10 January 2008).

23. Kerim Yildiz and Mark Muller, "Turkey, Kurds, Europe and the EU Accession Process: What Is To Be Done?" in EU Turkey Civic Commission: International Conference on Turkey, the Kurds and the EU, European Parliament, Brussels, 22-23 November 2004-Conference Papers, ed. Mark Muller, Claire Brigham, Kariane Westrheim, and Kerim Yildiz, 91-103 (London: KHRP, 2005), 97. 
24. Jon Rud, "Turkey's Implementation of European Human Rights Standards-Legislation and Practice," in EU Turkey Civic Commission: International Conference on Turkey, the Kurds and the EU, European Parliament, Brussels, 22-23 November 2004-Conference Papers, ed. Mark Muller, Claire Brigham, Kariane Westrheim, and Kerim Yildiz, 53-70 (London: KHRP, 2005), 65.

25. Zorab Aloian, "Kurdish Linguistic Rights Report, 2006: Submitted to the Translation and Linguistic Rights Committee of the International PEN at the Ohrid Conference, Republic of Macedonia, 14th-17th September 2006," Kurdish Info, 20 October 2006, http:// www.kurdishinfo.net/modules.php?name $=$ News\&file $=$ article\&sid $=4507$ (accessed 24 August 2007).

26. Richard Boudreaux, "Nameless Kurds of Turkey," Los Angeles Times, 30 January 2003, reproduced in Kurdistan Observer, http://home.cogeco.ca/ observer/3-2-03-namelesskurds.html (accessed 24 January 2008).

27. "Turkey Persists in Denial of Basic Cultural and Language Rights as Mayor Dismissed for Providing Multi-lingual Services" (KHRP press release, 18 June 2007), 1.

28. Ibid.

29. "Mayor Sacked for Providing Multilingual Services," Turkish Daily News, 16 June 2007, http://www.turkishdailynews.com.tr/article.php?enewsid=75989 (accessed 10 January 2008).

30. DTP Local Government Commission, “Appendix 2: Some of investigations and court cases launched against the DTP Mayors related to promotion or use of Kurdish on various occasions," in Report on Local Government and Local Democracy Dynamics Concerning the DTP Municipalities in Turkey, as reproduced in Mizgin Sen, "Neglecting the Principles of Democratization," Rastî, 24 March 2007, http://rastibini.blogspot.com/2007/03/neglectingprinciples-of.html (accessed 14 January 2008).

31. BIA News Center, 20 April 2006, cited in "Human Rights Activists: 'New Anti-Terror Bill Incites More Violence," Info Turk 332, April 2006, http://www.info-turk.be/ 332.htm\#Human (accessed 10 January 2008).

32. Quoted in BIA News Center, 22 September 2006, cited in "TIHV: 'Not Only 301, Fourteen Articles Need Change," Info Turk 337, September 2006, http://www.info-turk.be/337.htm\# Droits (accessed 10 January 2008). See also the protest letter addressed to Turkish president Necdet Sezer by Article 19, an NGO monitoring freedom of expression, www.article19.org/ pdfs/letters/turkey-amendments-to-terror-law.pdf (accessed 10 January 2008).

33. Fernandes, "Cause for Concern?"

34. Jon Rud, "Turkey's Implementation," 57.

35. Ibid.

36. Kurdish Democratic Party—Iraq, "General Information," http://www.kdp.pp.se/?do=kurdistan (accessed 11 January 2008).

37. Ibid.

38. Quoted in "Full Text of Iraqi Constitution," Washington Post, 12 October 2005, http:// www.washingtonpost.com/wp-dyn/content/article/2005/10/12/AR2005101201450.html (accessed 11 January 2008).

39. Kurdistan Democratic Party-Iraq, "Education in Iraqi Kurdistan,” http://www.kdp.pp.se/? do=edu (accessed 11 January 2008).

40. Katarina Tomasevski, The State of the Right to Education Worldwide. Free or Fee: 2006 Global Report (Copenhagen, August 2006), http://www.katarinatomasevski.com/ images/Global_Report.pdf (accessed 11 January 2008), 238, Table 25.

41. Abdulaziz S. Faris (Director General of Primary Schools and Kindergartens, Ministry of Education), in conversation with the author, Hawler/Erbil, March 2006.

42. Fakhradin Bahaddin (director general of Turkoman education, Ministry of Education) and Nazar Hana Khizo (director general of Assyrian education, Ministry of Education), in conversation with the author, Hawler/Erbil, March 2006.

43. For Assyrian-language education see, e.g., E.Y. Odisho, "Assyrian (Aramaic): A Recent Model for Its Maintenance and Revitalization," in Schools of Oriental Studies 
and the Development of Modern Historiography (Melammu Symposia IV), ed. A. Panaino and A. Piras, 183-96 (Milan: Università di Bologna and Istituto Italiano per l'Africa e l'Oriente, 2004).

44. Taib interview, 15 March 2006. This interview was conducted through the Ministry of Education's official Kurdish-English interpreter; the exact formulation was checked again - with the minister's brother, lawyer Mueyed Taib, acting as Kurdish-Swedish interpreter-at a private dinner with the minister and his brother on 17 March.

45. Skutnabb-Kangas, Linguistic Genocide in Education.

46. However, Nimrod Raphaeli, senior analyst of MEMRI's Middle East Economic Studies Program, writing in 2006, claims that "Kurdish and English will be the two leading languages, while Arabic, like the languages of other minorities, will be an elective subject. It is no secret that a whole new Kurdish generation, including many who studied at Kurdish universities, has little or no proficiency in Arabic. That situation raises a serious question about their future integration into a federated Iraq." Nimrod Raphaeli, "Kurdistan: The Quest for Statehood," MESOP_Near East News, 26 October 2006. Also see Odisho, "Assyrian (Aramaic)."

47. Convention on the Prevention and Punishment of the Crime of Genocide, 9 December 1948, 78 U.N.T.S. 277, http://www.unhchr.ch/html/menu3/b/p_genoci.htm (accessed 4 January 2008), art. 2.

48. Ibid. (emphasis added).

49. Pirjo Janulf, Kommer finskan $i$ Sverige att fortleva? En studie av språkkunskaper och sprakanvändning hos andragenerationens sverigefinnar $i$ Botkyrka och hos finlandssvenskar i A bo [Will Finnish Survive in Sweden? A Study of Language Skills and Language Use among Second-Generation Swedish Finns in Botkyrka, Sweden, and Finnish Swedes in Abo, Finland] (Stockholm: Almqvist \& Wiksell International, 1998), 2.

50. "Kitikmeot Struggles to Prevent Death of Inuktitut," quoted in Ian Martin, Aajjiqatigiingniq. Language of Instruction Research Paper: A Report to the Government of Nunavut (Iqaluit: Department of Education, Nunavut, 2000).

51. Edward Williams, Investigating Bilingual Literacy: Evidence from Malawi and Zambia (London: Department for International Development, 1998), 63-64.

52. Katherine Zozula and Simon Ford, Keewatin Perspective on Bilingual Education (1985), quoted in Martin, Aajjiqatigiingniq.

53. Quoted in Martin, ibid. See also Ian Martin, Sources and Issues: A Backgrounder to the Discussion Paper on Language of Instruction in Nunavut Schools (Iqaluit: Department of Education, Nunavut, 2000).

54. See Fernandes, "Kurdish Genocide"; Fernandes, "Cause for Concern?"; Fernandes, Kurdish and Armenian Genocides; Fernandes, Colonial Genocides; Fernandes, The Kurdish Genocide; Fernandes, Perspectives; Fernandes, Psychological Warfare Operations; Skutnabb-Kangas, Linguistic Genocide; Skutnabb-Kangas, "Human Rights in Education"; Skutnabb-Kangas, "Language Rights"; Skutnabb-Kangas and Bucak, "Killing a Mother Tongue"; Skutnabb-Kangas and Phillipson, "Kurdisch"; Skutnabb-Kangas and Phillipson, "Linguistic Genocide."

55. Stephen May, Richard Hill, and Sarah Tiakiwai, Bilingual/Immersion Education: Indicators of Good Practice (Final Report to the Ministry of Education) (Wellington: Ministry of Education New Zealand, 2004), http://www.educationcounts.govt.nz/_data/ assets/pdf_file/0009/6957/bilingual-education.pdf (accessed 24 January 2008), 64.

56. See Skutnabb-Kangas, "Language Rights."

57. See E. Annamalai, "Multilingualism for All-An Indian Perspective," in Multilingualism for All, ed. Tove Skutnabb-Kangas, 215-20 (Lisse: Swets \& Zeitlinger, 1995); E. Annamalai, "Language Choice in Education: Conflict Resolution in Indian Courts," Language Sciences 20, no. 1 (1998): 29-43; E. Annamalai, Managing Multilingualism in India (New Delhi: Sage, 2001); E. Annamalai, "Medium of Power: The Question of English in Education in India," in Medium of Instruction Policies: Which Agenda? Whose Agenda?, ed. Angel M.Y. Lin and Peter W. Martin, 20-37 (Clevedon, UK: Multilingual Matters, 2005); Ajit K. 
Mohanty, "Perpetuating Inequality: The Disadvantage of Language, Minority Mother Tongues and Related Issues," in Psychology of Poverty and Disadvantage, ed. Ajit K. Mohanty and Girishwar Misra, 104-17 (New Delhi: Concept Publishing, 2000); Ajit Mohanty, "Multilingualism of the Unequals and Predicaments of Education in India: Mother Tongue or Other Tongues?" in Imagining Multilingual Schools: Language in Education and Globalization, ed. Ofelia García, Tove Skutnabb-Kangas, and María Torres Guzmán, 262-83 (Clevedon, UK: Multilingual Matters, 2006).

58. Much of our analysis here builds on Fernandes, "Cause for Concern?"

59. For the period up to the early 1990s, see Skutnabb-Kangas and Bucak, "Killing a Mother Tongue." For the rest, see Fernandes, Colonial Genocides; Fernandes, The Kurdish Genocide.

60. Desmond Fernandes, "The Kurdish Genocide in Turkey, 1924-98," Armenian Forum 4 (1999): 57-107; Fernandes, "Cause for Concern?"; Fernandes, The Kurdish and Armenian Genocides; Fernandes, Colonial Genocides; Fernandes, The Kurdish Genocide; Fernandes, Psychological Warfare Operations.

61. Noam Chomsky, A New Generation Draws the Line: Kosovo, East Timor and the Standards of the West (London: Verso, 2001), 12-14.

62. Ibid.

63. Quoted in Fernandes, "Cause for Concern?", 8, 9.

64. “Who Are Guilty?” Devrimci Sol, January 1997, 31.

65. Fernandes, Psychological Warfare Operations; William Clark, "Byzantine Politics: The Abduction and Trial of Abdullah Öcalan," Variant: Cross Currents in Culture 8 (1999): 1-12, http://www.variant.randomstate.org/pdfs/issue8/Variant8supplement.pdf (accessed 25 August 2007).

66. UK Parliamentary Human Rights Group, A Desolation Called Peace: Report by the Parliamentary Human Rights Group on a Mission To Turkish Kurdistan, 12-17 October 1993 (London: Kurdish Information Centre, 1993), 28.

67. Global Campaign for Free Expression (Article 19), letter to the secretary general of the Council of Europe, 8 September 1997.

68. Karen Parker, "The Kurdish Insurgency in Turkey in Light of International Humanitarian Law," in The Kurdish Question and International Law: An Analysis of the Legal Rights of the Kurdish People, ed. Mohammed Ahmed and Michael Gunter (Oakton, VA: Ahmed Foundation for Kurdish Studies, 1999), 47-74.

69. Vijay Prashad, "Hot Turkey: US Authorised Kurdish Massacre," Economic and Political Weekly 31 (12-18 October 1996), 2799.

70. Fernandes, Psychological Warfare Operations.

71. Fernandes, "Cause for Concern?"; Fernandes, Psychological Warfare Operations.

72. Embassy of the United States in Ankara, "US Department of State Statement by Sean Mc Cormack, Spokesman: Special Envoy for Countering the PKK" (press release, Washington, DC, 28 August 2006).

73. Xinhua News Agency, news bulletin, 14 September 2006.

74. "US Threatens Kurds," Ozgur Gundem, 12 September 2005 [in Turkish], as reproduced in Fernandes, "Cause for Concern?" For similar statements by George W. Bush, see David Keen, Endless War? Hidden Functions of the "War on Terror" (London: Pluto, 2006), 8.

75. Here quoted from "Theodore Roosevelt on Immigrants," http://urbanlegends.about.com/ library/bl_roosevelt_on_immigrants.htm (accessed 24 January 2008). The contemporary "English Only" movement, for example, embraces a similar ideology. See U.S. English, Inc., http://www.us-english.org/inc/ (accessed 24 January 2008); James Crawford, "Issues in U.S. Language Policy: The English Only Movement" (1997), http://ourworld.compuserve. com/homepages/jWCRAWFORD/engonly.htm (accessed 24 January 2008).

76. Michael Gunter, Kurds and the Future of Turkey (New York: St. Martin's Press, 1997), 5, 6.

77. Quoted in Susan Meiselas, Kurdistan: In the Shadow of History (New York: Random House, 1997), 124.

78. Chris Morris, New Turkey: The Quiet Revolution on the Edge of Europe (London: Granta Books, 2006), 93. 
79. Quoted in Kendal, "Kurdistan in Turkey," 56.

80. Ismail Besikci, International Colony Kurdistan (Reading, UK: Taderon Press, 2004), 82.

81. Gunter, Kurds and the Future of Turkey, 6, 7.

82. State Prosecutor's Office, Van, Indictment to the Van No. 2 State Security Court Presidency (No. 2002/126), as reproduced (in English translation) in Benitez and Lawson, The Trial of Students, 63, 64.

83. Besikci, International Colony Kurdistan, 83, 98.

84. Gerard Chaliand, The Kurdish Tragedy (London: Zed Books, 1994), 33. Bozarslan's book was republished in Sweden in 1980.

85. Helsinki Watch, Destroying Ethnic Identity: The Kurds of Turkey (New York: Helsinki Watch, 1990), 37.

86. Quoted in Christopher Houston, Islam, Kurds and the Turkish Nation State (Oxford: Berg, 2001), 100.

87. Ibid., 95.

88. Quoted in Gunter, Kurds and the Future of Turkey, 63.

89. Quoted ibid., 62, 63. Pehlivanli made this statement in 1991. However, it has been noted that, even as "Law 2932, passed in 1983 (declaring the mother tongue of Turkish citizens to be

Turkish), was repealed in April 1991," proposals "were also floated for a relaxation of the ban on Kurdish in the print and broadcast media and in education, but such liberalization did not occur." Helen Chapin Metz, ed., Turkey: A Country Study (Washington, DC: GPO/Library of Congress, 1995), http://countrystudies.us/turkey/17.htm (accessed 25 August 2007).

90. Ibid., 80.

91. Ibid., 11.

92. Morris, New Turkey, 104, 105, 227.

93. Ibid., 227.

94. Ibid.

95. Baku Ceyhan Campaign, "The Companies Involved," http://www.bakuceyhan.org.uk/ more_info/companies.htm (accessed 14 January 2008).

96. Wikipedia, s.v. "Baku-Tbilisi-Ceyhan Pipeline," http://en.wikipedia.org/wiki/Baku-TbilisiCeyhan_pipeline (accessed 25 August 2007).

97. Michael Chossudovsky, "The War on Lebanon and the Battle for Oil," Global Research, 26 July 2006, http://www.globalresearch.ca/index.php?context=viewArticle\&code= CHO20060726\&articleId $=2824$ (accessed 14 January 2008).

98. Etgar Lefkovits, "Israel and Turkey Plan Energy Pipeline," Jerusalem Post, 11 May 2006.

99. See Fernandes, "Cause for Concern?"

100. William Hartung, Reports - Weapons at War (New York: Arms Trade Resource Center/ World Policy Institute, 1995), www.worldpolicy.org/projects/arms/reports/wawrep.html\# weapons (accessed 14 January 2008).

101. Kevin McKiernan, The Kurds: A People in Search of their Homeland (New York: St. Martin's Press, 2006), 64.

102. Noam Chomsky, "The New War Against Terror" (paper presented at the Technology and Culture Forum, MIT, 18 October 2001), http://www.islandnet.com/plethora/wtc/chomskyp2.html (accessed 14 January 2008).

103. See Dan Darling, "Tidbits from Turkey on Iran," Winds of Change, 21 December 2005, http://www.windsofchange.net/archives/tidbits_from_turkey_on_iran-print.php (accessed 24 August 2007); Fernandes, "Cause for Concern?"

104. Kevin McKiernan, quoted in Fernandes, "Cause for Concern?"

105. Leslie Wayne, "Free to a Good Country," New York Times, 31 October 2006, http:// www.nytimes.com/2006/10/31/business/31tagsale.html?_r=1\&th\&emc=th\&oref=slogin (accessed 14 January 2008).

106. Mizgin Yilmaz, as quoted in Fernandes, "Cause for Concern?" 36.

107. Fernandes, "Cause for Concern?"

108. This information appeared in the Dallas-Fort Worth Star-Telegram, and is quoted in Mizgin Yilmaz, "The US PKK Coordinator and Lockheed Martin," Rastî, 1 October 2006, 
http://rastibini.blogspot.com/2006/10/us-pkk-coordinator-and-lockheed-martin.html (accessed 14 January 2008).

109. “DoD OK's $\$ 2.9$ Billion Sale to Turkey of 30 F-16 Fighters," Market Watch, 29 September 2006, quoted in Fernandes, "Cause for Concern?"

110. Mizgin Yilmaz, "Lockheed Martin, Joseph Ralston and the PKK," Kurdish Info, 3 October 2006, http://www.kurdishinfo.net/modules.php?name $=$ News\&file=article\&sid $=4282$ (accessed 3 October 2007).

111. Kurdish National Congress-North America, "Demanding Immediate Resignation of General Ralston as Special Envoy in Turkey" (press release, 26 October 2006), reprinted in Kurdish Info, 27 October 2007, http://www.kurdish-info.net/ modules.php?name $=$ News\&file $=$ article $\&$ sid $=4566$ (accessed 25 August 2007).

112. Mizgin Yilmaz, quoted in Fernandes, "Cause for Concern?" 38-40.

113. Chomsky, A New Generation, 17.

114. William Clark, "Byzantine Politics: The Abduction and Trial of Abdullah Öcalan," Variant: Cross Currents in Culture 8, special supplement (1999): 1-12, http://www.variant.randomstate.org/pdfs/issue8/Variant8supplement.pdf (accessed 14 January 2008).

115. Reported in V. Vosbigian, "Seminar Discussing Kurdish and Armenian Genocides, 1915-99" (press release, London: KIC, Peace in Kurdistan Campaign, and United Kurdish Committee, 17 July 1999), 2. For a detailed discussion of this matter, see Desmond Fernandes, The Criminalization of Kurdish Asylum Seekers and Refugee Communities in the UK and Germany (London: Peace in Kurdistan Campaign, 2001); Fernandes, Psychological Warfare Operations; and Defend the Kurds Campaign, Discussion Document on the Case of PKK European Representative Kani Yilmaz, the Criminalization of Kurdish Communities in Britain and Europe and the Erosion of Democratic and Civil Rights (London: Defend the Kurds Campaign, 1996).

116. This meeting was held in Lyons, France, in June 1996.

117. For further details, see Defend the Kurds Campaign, Discussion Document.

118. "Top General Hints at Fight against Both the PKK and Barzani," Turkish Daily News, 1 June 2007.

119. Ibid.

120. Lale Sariibrahimoglu, "Is a Turkish Cross-Border Operation in the Offing?" Today's Zaman, 12 April 2007, http://www.todayszaman.com/tz-web/ yazarDetay.do?haberno=108147 (accessed 14 January 2008).

121. Mizgin Yilmaz, "Buyukanit Brays," Rastî, 12 April 2007, http://rastibini.blogspot.com/ 2007/04/buyukanit-brays.html (accessed 14 January 2008).

122. See, e.g., Nimrod Raphaeli, "The Opportunity Before Kurdistan: A New Model for Middle East Democracy" (Middle East Media Research Institute, 7 September 2005), http://web.krg.org/articles/detail.asp?rnr=77\&lngnr $=12 \& a n r=5863 \& s m a p=($ accessed 24 January 2008), quoting Khaled Al-Kishtainy, Iraqi columnist for the London daily newspaper Al-Sharq Al-Awsat.

123. For additional information about the situation of women see Shahrzad Mojab and Himani Bannerji, eds., "War and Militarization," special issue, Resources for Feminist Research 30, 3/4 (2003); for a recent account, listen to "Post-war Reconstruction and Democracy Promotion: Women's NGOs in Iraq," an interview with Shahrzad Mojab, http://www.kpfa.org/archives/index.php?arch=19061 (accessed 14 January 2008); the interview is based on Mojab's research, entitled Role of Women's Organization in Post-war Reconstruction: Diaspora-Homeland Relations in the Kurdish "Safe Haven," 1991-2003.

124. Yara Bayoumy and Shamal Aqrawi, "U.N. Criticises Iraq's Kurdistan on Press Freedom," Reuters, 25 April 2007.

125. Peter BetBasoo, Incipient Genocide: The Ethnic Cleansing of the Assyrians of Iraq (N.p.: Assyrian International News Agency, 2007).

126. For example, in March 2007 the Assyrian International News Agency (AINA) reported the following from Dohuk, in northern Iraq: "Kurdish authorities are preventing Assyrian 
businesses from using Assyrian names or putting up signs using the Assyrian language on the front of their stores, according to the Assyrian website assyrian4all.net [accessed 20 May 2007]. Kurdish authorities have informed they may use Kurdish or English only. An Assyrian businessman observed that this policy is no different from that under Saddam's regime, when Assyrians were forced to use Arabic instead of Assyrian names. "Kurdish Authorities Outlaw the Assyrian Language in North Iraq," AINA, 10 March 2007, http://www.aina.org/news/20070310144443.htm (accessed 14 January 2008). We sent the text of this news release to a colleague in Dohuk, lawyer Mueyed Taib, on 22 May 2007. He went out immediately to take pictures in Dohuk and e-mailed us a dozen within a couple of hours, showing Assyrian shop signboards and other texts outside buildings in Assyrian/Syriac, Assyrian colors flying from cars, and so on, and absolutely denied that the language would be forbidden.

127. John Pilger, Hidden Agendas (London: Vintage, 1998), 59.

128. Chomsky can be seen articulating this view, for example, when asked by an interviewer what he would say if he could spend one minute with George W. Bush: see "One Minute with George Bush" (uploaded to YouTube on 21 May 2006), http://www.youtube.com/ watch?v=aQ2LScRiz1U\&mode=related\&search= (accessed 24 January 2008).

129. See Deepa Fernandes, Targeted: National Security and the Business of Immigration (New York: Seven Stories Press, 2006); see also Jeffrey S. Passel, Randy Capps, and Michael Fix, "Undocumented Immigrants: Facts and Figures" (Urban Institute Immigration Studies Program, 12 January 2004), http://www.urban.org/UploadedPDF/ 1000587_undoc_immigrants_facts.pdf (accessed 14 January 2008); League of United Latin American Citizens, "The Truth about Undocumented Immigration," http://www.lulac.org/ advocacy/issues/immigration/truth.html (accessed 14 January 2008).

130. Mizgin Yilmaz, "Nexus of Evil-Part 1," Rastî, 17 March 2007, http://rastibini.blogspot.com/2007/03/nexus-of-evil-part-1.html (accessed 14 January 2008); Mizgin Yilmaz, "Nexus of Evil-Part 2," Rastî, 18 March 2007, http://rastibini.blogspot.com/2007/03/nexus-of-evilpart-2.html (accessed 14 January 2008).

131. Benito Mussolini is reported to have said that "Fascism should more appropriately be called corporatism because it is a merger of state and corporate power." Giovanni Gentile, ed., Encyclopedia Italiana, s.v. Benito Mussolini, quoted in Thomas J. DiLorenzo,

Economic Fascism, cited in Rick Parkany, "The Economics of War ..." (University of Milan, 2003), http://www.borg.com/ rparkany/PromOriginal/EconomyOfWar/

EconomicsOfWar.html (accessed 14 January 2008).

132. Patrick Hennessy, "Blair Entrusts Policy to Peace, Love and Harmony," Sunday Telegraph, 30 October 2006, http://www.telegraph.co.uk/news/main.jhtml?xml=/news/ 2006/10/29/nmemo129.xml (accessed 14 January 2008).

133. M.K. Gandhi, Gandhi on Non-violence: A Selection from the Writings of Mahatma Gandhi, ed. and introd. Thomas Merton (New York: New Directions, 1965), 54. 